Villanova School of Business Economics Working Paper \#49

January 2021

\title{
Optimal Bailouts in Banking and Sovereign Crises ${ }^{\dagger}$
}

\author{
Sewon Hur \\ Federal Reserve Bank of Dallas \\ sewonhur@gmail.com \\ César Sosa-Padilla \\ University of Notre Dame \\ and NBER \\ csosapad@nd.edu \\ Zeynep Yom \\ Villanova University \\ zeynep.yom@villanova.edu
}

\begin{abstract}
We study optimal bailout policies in the presence of banking and sovereign crises. First, we use European data to document that asset guarantees are the most prevalent way in which sovereigns intervene during banking crises. Then, we build a model of sovereign borrowing with limited commitment, where domestic banks hold government debt and also provide credit to the private sector. Shocks to bank capital can trigger banking crises, with government sometimes finding it optimal to extend guarantees over bank assets. This leads to a trade-off: Larger bailouts relax domestic financial frictions and increase output, but also imply increasing government fiscal needs and possible heightened default risk (i.e., they create a 'diabolic loop'). We find that the optimal bailouts exhibit clear properties. Other things equal, the fraction of banking losses that the bailouts would cover is: (i) decreasing in the level of government debt; (ii) increasing in aggregate productivity; and (iii) increasing in the severity of the banking crisis. Even though bailouts mitigate the adverse effects of banking crises, we find that the economy is ex ante better off without bailouts: the 'diabolic loop' they create is too costly.
\end{abstract}

Keywords: Bailouts, Sovereign Defaults, Banking Crises, Conditional Transfers, Sovereign-bank diabolic loop.

JEL Classification CODEs: E32, E62, F34, F41, G01, G15, H63.

\footnotetext{
†We thank Pablo D’Erasmo, Alok Johri, Illenin Kondo, Chengying Luo, Yun Pei, Jing Zhang, and participants at University of Pittsburgh, the CSWEP CeMENT workshop, and the Sovereign Debt Workshop (Sogang University) for insightful discussions. This research was supported in part through a grant from Villanova University and computational resources provided by the Big-Tex High Performance Computing Group at the Federal Reserve Bank of Dallas. The views expressed herein are those of the authors and not necessarily those of the Federal Reserve Bank of Dallas or the Federal Reserve System. First draft: February 2020.
} 


\section{Introduction}

The recent European debt crisis highlighted the 'diabolic loop' between sovereign risk and bank risk. On the one hand, the Irish bailout of 2008 illustrated how bailouts and asset guarantees can shift financial risk to the government (Acharya, Drechsler and Schnabl, 2014). On the other hand, the Greek debt crisis of 2012 showed how sovereign risk can weaken banks' balance sheets due to overexposure to government debt (Sosa-Padilla, 2018). In the presence of this diabolic loop, how much - if at all - should the government intervene to 'save' the domestic banking sector during banking crises?

To answer this question, we build a quantitative model that features a rich interaction between sovereign and banking risk. To mitigate the adverse effects of banking crises, which reduce loans to the private sector and thereby decrease output, the government may find it optimal to bail out banks. Bailouts come with a trade-off, allowing the government to boost liquidity and output during banking crises but increasing sovereign debt and default risk. Sovereign defaults weaken bank balance sheets, completing the 'diabolic loop.' In this environment, we find that it is optimal, from an ex ante perspective, to ban bailouts. Without bailouts, the diabolic loop is severed and this dominates the ex post benefits of bailing banks out.

We model bailouts as contingent guarantees over bank capital. This is guided by empirical evidence from the recent European sovereign debt crisis. In section 2, we document that the issuance of sovereign guarantees is the most prevalent form of intervention during banking crises. Among European countries, the average share of government guarantees relative to GDP is four times larger than the average share of direct capital transfers during banking crises - a relationship that does not hold during normal times.

Every period, the economy observes the realization of a productivity shock and a bank capital shock, which represents the fraction of bank capital that could become lost if a banking crisis materialized. In response, the government chooses the amount of potential capital losses to guarantee. These guarantees (bailouts) are financed with a mix of new borrowing and distortionary taxation. The government lacks commitment to repay, and if it should default, it temporarily loses access to new borrowing and cannot extend bailouts.

We calibrate our model using data from European countries facing sovereign risk. Our model matches salient moments in the data, both targeted and untargeted. We show that the occurrence of a banking crisis increases the default probability (from 0.5 to 0.7 percent annually), resulting in sovereign spreads that are higher (from 0.7 to 0.9 percent) and more volatile (from 0.6 to 1.0 percent). The government finds it optimal to issue bailouts (i.e. 
contingent guarantees) that are on average 1.7 percent of GDP during banking crises.

We further validate the model by comparing the dynamics around banking crises with the data. We find that banking crises are associated with sharp output contractions and sovereign yield spikes. Furthermore, governments that experience a banking crisis with high debt levels face deeper and longer recessionary dynamics and higher spreads. These dynamics are consistent with the data.

Using the calibrated model, we study the ex post optimal properties of bailouts. Other things equal, the fraction of banking losses that the bailouts would cover: (i) increase with the severity of the banking crisis, because the impact of bank capital shocks is nonlinearsmall shocks negligibly affect lending to the private sector, whereas large shocks can generate a severe private credit crunch absent government intervention; (ii) decrease relative to the level of government debt, since a more indebted government has less fiscal space to prop up banking sector assets; and (iii) increase with aggregate productivity, since the better the economy's overall state, the more valuable credit is and the cheaper it is to borrow to provide the guarantees.

Our model has implications for the design of institutions that govern bailouts. Is it optimal from an ex ante perspective to allow governments to bail out the banking sector, knowing that this may lead to higher default risk? We find that the costs of bailouts (higher sovereign risk) outweigh the benefits (ability to increase liquidity during banking crises). Even though the welfare gains of maintaining access to bailouts are state-contingent, we find that for the empirically relevant cases (i.e., economies with moderate to high initial debt levels), the country is better off avoiding bailouts altogether. This is because governments not providing bailouts enjoy lower interest rates despite sustaining higher levels of debt, as they default less frequently.

Related literature. This paper belongs to the quantitative literature on sovereign debt and default, following the contributions of Eaton and Gersovitz (1981), Aguiar and Gopinath (2006) and Arellano (2008). Our work differs from these early papers, in that it presents a model that entails a rich interaction between the government and the financial sector to study the transmission of risks between these sectors and their implications on the real economy.

Our paper is at the intersection of two strands in the literature. The first uses dynamic quantitative models of sovereign risk to examine how the banking channel amplifies the effects of sovereign risk. The closest paper to ours is Sosa-Padilla (2018), which studies how a sovereign default affects banks' balance sheets and creates a private sector credit crunch, endogenizing output declines in that way. Bocola (2016) studies the macroeconomic 
implications of increased sovereign risk in a model, where banks are exposed to government debt. His framework takes default risk as given and shows how anticipation of a default can be recessionary on its own. Perez (2015) also studies the output costs of default when domestic banks hold government debt. Public debt serves two roles in his framework: It facilitates international borrowing and it provides liquidity to domestic banks. In addition to the bank balance sheet effects highlighted in these studies, our paper also incorporates the transmission of banking crises to sovereign crises, which these papers do not consider. ${ }^{1}$

The second strand of the literature to which we are especially related is the one studying the feedback loop between sovereign risk and bank risk, the so-called 'doom loop.' Acharya et al. (2014) model a stylized economy where bank bailouts (financed via a combination of increased taxation and increased debt issuance) can solve an underinvestment problem in the financial sector, but exacerbate another underinvestment problem in the non-financial sector. Higher debt needed to finance bailouts dilutes the value of previously issued debt, increases sovereign risk, and creates a feedback loop between bank risk and sovereign risk because banks hold government debt in their portfolios. Cooper and Nikolov (2018) and Farhi and Tirole (2018) also study the dynamic interaction between sovereign debt and the banking system and show the conditions (in their respective theoretical models) under which a bailout-induced doom loop may arise.

We borrow insights from these papers and focus on the ex ante optimal properties of bailouts using a quantitative model calibrated to recent GIIPS (Greece, Italy, Ireland, Portugal and Spain) data. We also differ from these papers in that we model bailouts as contingent guarantees over bank capital (motivated by the evidence in section 2).

The existing literature is split on the desirability of bailouts. For example, Bianchi (2016) and Keister (2016) study bailouts, abstracting from sovereign risk, and find that bailouts can be desirable even when taking into account moral hazard consequences. Our main departure from this literature is the consideration of sovereign risk, whereby bailouts can lead to a 'doom loop.' In this environment, we find that bailouts are ex ante suboptimal for the empirically relevant states of initial debt, even in the absence of moral hazard concerns. Farhi and Tirole (2018) and Cooper and Nikolov (2018), share our prescription: If at all possible, a country is better off ruling out bank bailouts. These papers also have theories

\footnotetext{
${ }^{1}$ The theoretical work on sovereign risk and bank fragility is vast. A branch of the literature uses stylized models of domestic and external sovereign debt in which domestic debt weakens the balance sheets of banks (e.g., Bolton and Jeanne, 2011, Gennaioli, Martin and Rossi, 2014, Gaballo and Zetlin-Jones, 2016, and Balloch, 2016). Other papers, more quantitative in nature, explicitly consider how banks are either affected by or amplify default risk (e.g., Boz, D'Erasmo and Durdu, 2014, Mallucci, 2015, Thaler, 2018, Abad, 2019, Guo and Pei, 2020, and Moretti, 2020). Without explicitly modeling banks, Arce (2020) studies how government bailouts of the private sector can lead to increased sovereign risk.
} 
of bailout-induced diabolic loops and we differ from them in that we provide a quantitative model with a strategic default decision. Finally, there are papers that assume an exogenous level of initial debt, and therefore focus on the ex post effects of bailouts. ${ }^{2}$

On the policy side, various proposals have aimed at lowering the fragility of the banking sector and its exposure to sovereign risk. Examples include the implementation of eurobonds (Favero and Missale, 2012) or the creation of European Safe Bonds (Brunnermeier, Langfield, Pagano, Reis, Van Nieuwerburgh and Vayanos, 2017). These proposals highlight how important it is to have reliable estimates of the dynamic relationship between sovereign risk, bank fragility, and economic activity. We provide a quantification of the role that government bailouts play in these dynamics.

Finally, our paper also relates to the large literature on country bailouts, either from a central authority (such as the ECB or IMF) or from another individual country. Contributions inspired by the recent European debt crisis include Gourinchas, Martin and Messer (2020), Azzimonti and Quadrini (2019), Pancrazi, Seoane and Vukotić (2020), Roch and Uhlig (2018), and De Ferra and Mallucci (2020), among others. These authors typically focus on moral hazard concerns and (the lack of) policy coordination. We view our work as complementary to theirs since our focus is on domestic governments bailing out their own banking sector and we abstract from moral hazard considerations. ${ }^{3}$

The rest of the paper is organized as follows: Section 2 summarizes the stylized facts that motivate the theoretical model presented in the rest of the paper. Section 3 introduces the model. Section 4 explains the calibration of the model, presents the quantitative results, and discusses the properties of the optimal policies. Section 5 discusses the optimality of bailouts. Section 6 concludes.

\section{Motivating Facts}

The nexus between sovereign and banking crises is not a new phenomenon and different aspects of it have been studied previously. In this section, we highlight three features of banking and sovereign debt crises that motivate our study: (i) defaults and banking crises tend to happen together, (ii) domestic banking sectors are highly exposed to government debt and this exposure tends to be greater during crises, and (iii) the most prevalent form

\footnotetext{
${ }^{2}$ For instance, Capponi, Corell and Stiglitz (2020) find that governments should bailout banks that have a high 'network centrality' and Acharya et al. (2014) derive conditions under which the ex post optimal bailout is non-zero.

${ }^{3}$ Naturally, this paper is also related to the body of work on government bailouts of banks that abstracts from sovereign risk considerations. For recent examples, see Niepmann and Schmidt-Eisenlohr (2013) and Keister (2016).
} 
of government intervention (during banking crises) is issuance of asset guarantees.

- Default and Banking crises tend to happen together. This is a well established fact. Reinhart (2010) documents 82 banking crises, of which 70 are accompanied by sovereign defaults. Focusing on more recent data, Balteanu, Erce and Fernandez (2011) identify 121 sovereign defaults and 131 banking crises for 117 emerging and developing countries from 1975 to 2007. Among these, they find 36 "twin crises" (defaults and banking crises). In 19 of them, a sovereign default preceded the banking crisis and in 17 the reverse was true, suggesting that both directions of causality are likely at play. ${ }^{4}$

- Banks are exposed to sovereign debt and this exposure is higher during crises. Gennaioli, Martin and Rossi (2018) report an average bank exposure ratio (net credit to the government as a fraction of bank assets) of 9.3 percent using data from both advanced and developing countries. When they focus only on defaulting countries, they find an exposure ratio of roughly 15 percent. Similarly, Abad (2019) documents that the banking sectors in Spain and Italy increased their exposure to domestic sovereign debt during the recent European debt crisis (with exposure ratios increasing by 8 percentage points).

Our own empirical contribution is to document a third motivating fact regarding how governments intervene during banking crises. Specifically,

- Issuance of sovereign guarantees is the most prevalent form of government intervention to alleviate banking crises. European Union governments have largely intervened in two ways - via asset guarantees and capital transfers. Using data from Eurostat, we construct the average net annual change in government guarantees and average capital transfers as a percentage of GDP in the 23 EU countries from 2007 to 2019. ${ }^{5}$ Figure 1 shows that governments mostly rely on asset guarantees rather than capital transfers as the way to intervene during banking crises (defined following Laeven and Valencia, 2013). We find that the average change of government guarantees as a fraction of GDP is close to 1.7 percent during banking crises, whereas it is close to zero in the overall sample. We also find that the change in capital transfers is less different across the two time periods, suggesting that transfers figure less prominently in government

\footnotetext{
${ }^{4}$ Another empirical study documenting this fact is the one by Borensztein and Panizza (2009). They construct an index of banking crises that includes 149 countries for the period 1975-2000. In this sample, they identify 111 banking crises (implying an unconditional probability of having a crisis equal to 2.9 percent) and 85 default episodes (unconditional default probability of 2.2 percent). When conditioned on a sovereign default episode, the probability of a banking crisis increases by a factor of 5 .

${ }^{5}$ See Appendix B for the details.
} 
Figure 1: Government guarantees and capital transfers

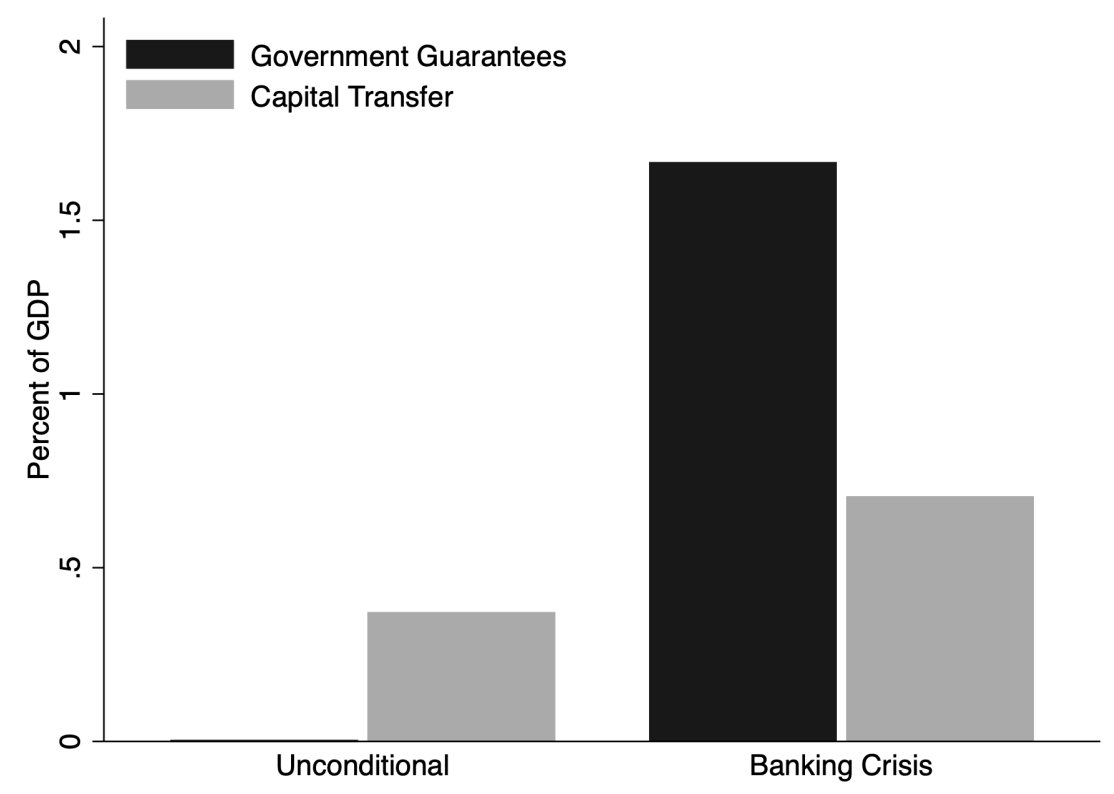

banking crisis intervention. In Appendix A, we show that a similar pattern holds for "contingent liabilities" (a broader definition of asset guarantees).

\section{Model}

We extend the banking and sovereign default model of Sosa-Padilla (2018) in two dimensions: banking crises that are driven by exogenous shocks to bank capital in addition to the bank balance sheet effects triggered by increased sovereign risk, and government bailouts that can mitigate a banking crisis but may trigger sovereign default crises.

Environment. We consider a closed economy populated by four agents: households, firms, banks, and a government. Households supply labor to firms, but do not face any intertemporal decisions. Firms hire labor and borrow working capital loans from banks to produce a consumption good. Banks lend to both firms and the government and are subject to a lending constraint. Additionally, banks are subject to shocks to the value of their capital. Finally, the government is a benevolent one (i.e., it maximizes household utility). It faces an exogenous stream of spending that must be financed and it can also provide contingent guarantees to the banks. To meet its obligations, the government has three (endogenous and potentially time-varying) instruments: labor income taxes, borrowing, and default. 
Debt contracts are unenforceable and the government may default on its debt. We assume defaults are total: All debt is erased. If the government decides to default, it gets excluded from the credit market for a random number of periods. During this time, the government cannot conduct bailouts.

There are four aggregate state variables in our model economy: one endogenous and three exogenous. The level of government debt, $B$, is the endogenous state variable. The first exogenous state variable is aggregate productivity $z$, which follows a Markov process. The second exogenous state variable, $\varepsilon$, captures the fraction of bank capital that could be lost and follows an iid process. We denote $s=\{z, \varepsilon\}$. The third exogenous state variable, $A$, is the realized level of bank capital: With probability $1-\pi$ this level is unaffected (and equal to a baseline value, $\bar{A})$; with probability $\pi$ it is reduced to $(1-\varepsilon) \bar{A}$.

Timing of events. If the government enters the period in good credit standing, then the sequence of events is as follows:

1. The aggregate state $s$ is realized

2. Considering the aggregate state $(B, s)$, the government decides whether to repay $(d=$ $0)$ or to default $(d=1)$

3. If $d=0$, then:

(a) the government announces a bailout policy

(b) given the bailout policy, banks decide their loan supply

i. with probability $\pi$, the bank's capital is reduced by $\varepsilon$, and the government disburses the promised bailouts

ii. with probability $1-\pi$, the bank's capital is unaffected, and the government does not pay any bailouts

(c) all other private decisions occur

(d) the government chooses its borrowing policy $B^{\prime}(B, s, A)$

4. If $d=1$, then:

(a) the government cannot promise bailouts and is excluded from financial markets

(b) banks determine their loan supply

(c) with probability $\pi$, the bank's capital is reduced by $\varepsilon$

(d) all private decisions occur. 
If the government enters the period in bad credit standing (i.e. it finished the previous period excluded from financial markets), the government regains market access with probability $\theta$. If it regains market access, then the timing of events is as above, with an initial debt level of zero. Otherwise, if the government remains excluded, the timing of events amounts to the sequence of stages 1 and 4 above.

\subsection{Decision problems given government policy}

Households. The only decisions of the households involve the labor supply and consumption levels. Therefore, the problem faced by the households can be expressed as:

$$
\begin{aligned}
\max _{\{c, n\}} & U(c, n) \\
\text { s.t. } & c=(1-\tau) w n+\Pi^{F},
\end{aligned}
$$

where $U(c, n)$ is the period utility function, $c$ stands for consumption, $n$ denotes labor supply, $w$ is the wage rate, $\tau$ is the labor-income tax rate, and $\Pi^{F}$ represents the firms' profits. The solution to the problem requires:

$$
-\frac{U_{n}}{U_{c}}=(1-\tau) w
$$

which is the usual intratemporal optimality condition equating the marginal rate of substitution between leisure and consumption to the after-tax wage rate. Therefore, the optimality conditions from the households' problem are equations (2) and (3).

Firms. The firms demand labor to produce the consumption good. They face a working capital constraint that requires them to pay upfront a certain fraction of the wage bill, which they do with intra-period bank loans. Hence, the problem is:

$$
\begin{aligned}
\max _{\left\{N, \ell^{d}\right\}} & \Pi^{F}=z F(N)-w N-r \ell^{d} \\
\text { s.t. } & \gamma w N \leq \ell^{d}
\end{aligned}
$$

where $z$ is aggregate productivity, $F(N)$ is the production function, $\ell^{d}$ is the demand for working capital loans, $r$ is the interest rate charged for these loans, and $\gamma$ is the fraction of the wage bill that must be paid upfront.

Equation (5) is the working capital constraint. This equation will always hold with equality because firms do not need loans for anything other than paying $\gamma w N$; thus, any 
borrowing over and above $\gamma w N$ would be sub-optimal. Taking this into account, we obtain the following first-order condition:

$$
z F_{N}(N)=(1+\gamma r) w
$$

which equates the marginal product of labor to the marginal cost of hiring labor once the financing cost is factored in. Therefore, the optimality conditions from the firms' problem are represented by equation (5), evaluated with equality, and equation (6).

Banks. Banks play a vital role in the economy by providing loans to both the government and the firms. They face a lending constraint requiring that loans to firms do not exceed the value of its loanable resources. These resources amount to the sum of three components: $b, A$, and $T$. The first component is the banks' holdings of sovereign bonds, $b$. The second component is banks' capital, $A$, which is subject to aggregate shocks. The third component is government guarantees, $T(B, s, A)$ (i.e. the state-contingent bailouts that the government may provide).

The dynamics of bank capital are as follows: Every period, bank capital has a reference value of $\bar{A}$ that is subject to shocks; $\varepsilon$, which represent the fraction of bank capital that could be lost. The magnitude of the shock $\varepsilon$ is realized at the beginning of the period, but uncertainty regarding whether the shock hits the banks is only resolved at the end of the period. With probability $\pi$, the bank's capital is reduced by $\varepsilon$, and with probability $1-\pi$, the bank's capital is unaffected. These dynamics can be summarized as

$$
A= \begin{cases}\bar{A} & \text { with probability } 1-\pi \\ (1-\varepsilon) \bar{A} & \text { with probability } \pi\end{cases}
$$

Let $\underline{A}(\varepsilon)=(1-\varepsilon) \bar{A}$. We refer to the event that $A=\underline{A}(\varepsilon)$ and $\varepsilon>0$ as a banking crisis. ${ }^{6}$

The lending constraint faced by banks is such that it must be satisfied in every possible state. This implies that in every period the supply of loans is limited by the worst-case scenario of the banks' loanable funds:

$$
\ell^{s} \leq \min _{A}\{A+b+T(B, s, A)\}
$$

\footnotetext{
${ }^{6}$ While we describe shocks to $A$ as fluctuations in banks' capital, they could more broadly be interpreted to include: (a) domestic bank runs (as they will affect the funding side of the banks' balance sheet), (b) shocks to the valuation of holdings of foreign debt (as highlighted in Gunn and Johri, 2018), and (c) global shocks (e.g. 'sudden stops' that may be transmitted through cross-border banking networks).
} 
This constraint, in a stylized way, is intended to capture the idea that (a) increased uncertainty about the state of the banking sector can spill over into the real economy, and (b) the government can prevent banking sector shocks from causing contractions in output by issuing bailouts.

When the government has access to credit, the value function of the representative bank is given by

$$
\begin{gathered}
W^{R}(b ; B, s)=\max _{\ell^{s}} \mathbb{E}_{A}\left\{\begin{array}{ll}
\max _{x, b^{\prime}} & x+\delta \mathbb{E}_{s^{\prime} \mid s}\left[\left(1-d^{\prime}\right) W^{R}\left(b^{\prime} ; B^{\prime}, s^{\prime}\right)+d^{\prime} W^{D}\left(s^{\prime}\right)\right] \\
\text { s.t. } & x \leq T(B, s, A)+b-q\left(B^{\prime}, s\right) b^{\prime}+r(B, s, A) \ell^{s}
\end{array}\right\} \\
\text { s.t. (8) }
\end{gathered}
$$

where $x$ is consumption, $\delta$ is the banks' discount factor, $r(B, s, A)$ is the interest rate on private loans, $q\left(B^{\prime}, s\right)$ is the price of government bonds, and $B^{\prime}, T$, and $d$ are government policies for debt, bailouts, and default, which the banks take as given. $W^{d}$ is the value of the representative bank when the government does not have access to credit, which is given by

$$
\begin{array}{rl}
W^{D}(s)=\max _{\ell^{s}, x} & x+\delta \mathbb{E}_{s^{\prime} \mid s}\left[\theta W^{R}\left(0 ; 0, s^{\prime}\right)+(1-\theta) W^{D}\left(s^{\prime}\right)\right] \\
\text { s.t. } x \leq r_{\operatorname{def}}(s) \ell^{s} \\
\quad \ell^{s} \leq \underline{A}(\varepsilon)
\end{array}
$$

where $\theta$ is the probability that the government regains access to credit and $r_{\text {def }}(s)$ is the interest rate on private loans when the government does not have access to credit. In this case, the banker can provide loans only up to the adverse realization of its loanable funds, given by equation (12).

\subsubsection{Characterization of equilibrium given government policies}

Hereafter, we focus on bailout policies that take the form:

$$
\begin{cases}T=0 & \text { if } A=\bar{A} \\ 0 \leq T \leq \varepsilon \bar{A} & \text { if } A=(1-\varepsilon) \bar{A}\end{cases}
$$

In other words, the government cannot provide bailouts if the adverse bank capital shock does not materialize, and it can only cover a sum not to exceed the amount of the bank's capital loss if the shock does materialize. In that sense, we also refer to the bailouts as 
government guarantees.

Loan market. When the government does not have access to credit, banks supply

$$
\ell_{\mathrm{def}}^{s}(s)=\underline{A}(\varepsilon) .
$$

When the government has access to credit, banks supply

$$
\ell^{s}(B, s)=B+\underline{A}(\varepsilon)+T(B, s, \underline{A}(\varepsilon)) \text {. }
$$

Note that the loan supply does not depend on the realization of $A$. Instead, given our restrictions on government bailout policies, the total loan supply is determined by the level of government debt $(B)$, the reduced bank capital $\underline{A}(\varepsilon)$, and government transfers $T$.

The demand for intra-period loans comes from the firms. Combining equations (6) and (5) (with equality) we obtain the following loan demand function:

$$
\ell^{d}(B, s, A)=\gamma\left[\frac{z n F_{n}}{1+\gamma r}\right]
$$

Note that the loan demand depends on the realization of $A$. This is because during a banking crisis $(A=\underline{A}(\varepsilon)$ with $\varepsilon>0$ ), the government may need to raise distortionary labor income taxes to pay for the bailouts, affecting equilibrium labor.

It is then straightforward to derive the equilibrium conditions for the loan rate under repay and default:

$$
r(B, s, A)=\max \left\{\frac{z n(B, s, A) F_{n}}{B+\underline{A}(\varepsilon)+T(B, s, \underline{A}(\varepsilon))}-\frac{1}{\gamma}, 0\right\}
$$

and

$$
r_{\text {def }}(s)=\max \left\{\frac{z n_{\text {def }}(s) F_{n}}{\underline{A}(\varepsilon)}-\frac{1}{\gamma}, 0\right\} .
$$

As was the case in Sosa-Padilla (2018), there is the possibility that the interest rate that clears the loan market in (17) or (18) is not strictly positive. In that case, the equilibrium loan amount is demand determined. Notice that a default shrinks the supply of loanable funds and, other things equal, increases the rate on the working capital loans. This increase in the loan rate arises from two reasons: Bonds are not repaid and the government is unable to extend bailouts during defaults. 
Government bond market. After the proceeds from private loans are received (recall these are intra-period loans), the banks invest in government bonds before the end of the period. These bonds are the only way to transfer resources across time, and they are priced according to their inherent default risk. The bond pricing function satisfies

$$
q\left(B^{\prime} ; s\right)=\delta \mathbb{E}_{s^{\prime} \mid s}\left\{[1-\underbrace{d\left(B^{\prime}, s^{\prime}\right)}_{\text {default premium }}] \mathbb{E}_{A^{\prime}}[1+\underbrace{r\left(B^{\prime}, s^{\prime}, A^{\prime}\right)}_{\text {lending discount }}]\right\}
$$

This expression shows that in the case of a default in the next period, $d\left(B^{\prime}, s^{\prime}\right)=1$, the lender loses not only the original sovereign bond investment but also future gains that those bonds would have created had they been repaid. These gains are captured by $\mathbb{E}_{A^{\prime}}\left[r\left(B^{\prime}, s^{\prime}, A^{\prime}\right)\right]$

\subsection{Determination of government policies}

The government's optimization problem can be written recursively as:

$$
V(B, s)=\max _{d \in\{0,1\}}\left\{(1-d) V^{R}(B, s)+d V^{D}(s)\right\}
$$

where $V^{R}$ and $V^{D}$ are the values of repaying and defaulting, respectively. Let $\kappa \equiv(B, s, A)$ denote the complete aggregate state and $\Phi \equiv\left\{\tau, T, B^{\prime}\right\}$ summarize the fiscal policies under repay. The value of repaying is:

$$
V^{R}(B, s)=\max _{\Phi} \mathbb{E}_{A}\left\{U(c(\kappa ; \Phi), n(\kappa ; \Phi))+\beta \mathbb{E}_{s^{\prime} \mid s} V\left(B^{\prime}, s^{\prime}\right)\right\}
$$

subject to:

$$
\begin{array}{llr}
\tau w(\kappa ; \Phi) n(\kappa ; \Phi)+B^{\prime} q\left(B^{\prime}, s\right)=g+B+T & \text { (gov't b.c.) } \\
c(\kappa ; \Phi)+x(\kappa ; \Phi)+g=z F(n(\kappa ; \Phi)) & \text { (resource constraint) } \\
\left.\begin{array}{ll}
T=0 & \text { if } A=\bar{A} \\
0 \leq T \leq \varepsilon \bar{A} & \text { if } A=\bar{A}(1-\varepsilon)
\end{array}\right\} & \text { (constraint on } T \text { ) }
\end{array}
$$

and 


$$
\left.\begin{array}{l}
q\left(B^{\prime}, s\right)=\delta \mathbb{E}_{s^{\prime} \mid s}\left\{\left[1-d\left(B^{\prime}, s^{\prime}\right)\right] \mathbb{E}_{A^{\prime}}\left[1+r\left(\kappa^{\prime} ; \Phi^{\prime}\right)\right]\right\} \\
r(\kappa ; \Phi)=\max \left\{\frac{z n(\kappa ; \Phi) F_{n}}{B+\underline{A}(\varepsilon)+T(\underline{A}(\varepsilon))}-\frac{1}{\gamma}, 0\right\} \\
-\frac{U_{n}}{U_{c}}=(1-\tau) w(\kappa ; \Phi) \\
z F_{n}=(1+\gamma r(\kappa ; \Phi)) w(\kappa ; \Phi) \\
\ell(\kappa ; \Phi)=\gamma w(\kappa ; \Phi) n(\kappa ; \Phi) \\
x(\kappa ; \Phi)=T+B-q\left(B^{\prime}, s\right) B^{\prime}+r(\kappa ; \Phi) \ell(\kappa ; \Phi)
\end{array}\right\} \quad \text { (comp. eq. conditions) }
$$

where $c(\kappa ; \Phi), n(\kappa ; \Phi), x(\kappa ; \Phi), \ell(\kappa ; \Phi), w(\kappa ; \Phi), r(\kappa ; \Phi)$, and $q\left(B^{\prime}, s\right)$ represent the equilibrium quantities and prices for the private sector given public policy (under repayment).

The value of default is:

$$
V^{D}(s)=\max _{\tau} U\left(c_{\mathrm{def}}(s ; \tau), n_{\mathrm{def}}(s ; \tau)\right)+\beta \mathbb{E}_{s^{\prime} \mid s}\left[\theta V\left(0, s^{\prime}\right)+(1-\theta) V^{D}\left(s^{\prime}\right)\right]
$$

subject to:

$$
\left.\begin{array}{lr}
\tau w_{\text {def }}(s ; \tau) n_{\text {def }}(s ; \tau)=g & \text { (gov't b.c.) } \\
c_{\text {def }}(s ; \tau)+x_{\text {def }}(s ; \tau)+g=z F\left(n_{\text {def }}(s ; \tau)\right) & \text { (resource constraint) } \\
r_{\text {def }}(s ; \tau)=\max \left\{\frac{z n_{\text {def }}(s ; \tau) F_{n}}{\underline{A}(\varepsilon)}-\frac{1}{\gamma}, 0\right\} \\
-\frac{U_{n}}{U_{c}}=(1-\tau) w_{\text {def }}(s ; \tau) \\
z F_{n}=\left(1+\gamma r_{\text {def }}(s ; \tau)\right) w_{\text {def }}(s ; \tau) \\
\ell_{\text {def }}(s ; \tau)=\gamma w_{\text {def }}(s ; \tau) n_{\text {def }}(s ; \tau) \\
x_{\text {def }}(s ; \tau)=r_{\text {def }}(s ; \tau) \ell_{\text {def }}(s ; \tau)
\end{array}\right\} \quad \text { (comp. eq. conditions) }
$$

where $c_{\text {def }}(s ; \tau), n_{\text {def }}(s ; \tau), x_{\text {def }}(s ; \tau), \ell_{\text {def }}(s ; \tau), w_{\text {def }}(s ; \tau)$, and $r_{\text {def }}(s ; \tau)$ represent the equilibrium quantities and prices for the private sector given public policy (under default).

\subsubsection{Equilibrium definition}

A Markov-perfect equilibrium is then defined as follows:

Definition 3.1. A Markov-perfect equilibrium for this economy is (i) a set of value functions for the government $\left\{V(B, s), V^{R}(B, s), V^{D}(s)\right\}$; (ii) a set of government policy rules for borrowing $B^{\prime}(\kappa)$, taxation $\tau(\kappa)$, bailouts $T(\kappa)$, and default $d(B, s)$; (iii) a set of decision rules and prices from the private sector under repay $\{c(\kappa ; \Phi), n(\kappa ; \Phi), x(\kappa ; \Phi), \ell(\kappa ; \Phi), w(\kappa ; \Phi), r(\kappa ; \Phi)\}$, and under default $\left\{c_{\mathrm{def}}(s ; \tau), n_{\mathrm{def}}(s ; \tau), x_{\mathrm{def}}(s ; \tau), \ell_{\mathrm{def}}(s ; \tau), w_{\mathrm{def}}(s ; \tau), r_{\mathrm{def}}(s ; \tau)\right\} ;$ and (iv) an equilibrium pricing function for the sovereign bond $q\left(B^{\prime}, s\right)$, such that: 
1. Given prices and private sector decision rules, the borrowing, tax, bailout, and default rules solve the government's maximization problem in (20)-(22).

2. Given the price $q\left(B^{\prime}, s\right)$ and government policies, the decision rules and prices of the private sector are consistent with the competitive equilibrium.

3. The equilibrium price function satisfies equation (19).

\section{Quantitative Analysis}

In this section, we first describe how we set the parameters of the model. Second, we examine the ability of our model to account for salient features of the data in GIIPS countries. Third, we describe the properties of the optimal default and bailout policies.

\subsection{Functional forms and stochastic processes}

The period utility function of the households is given by

$$
U(c, n)=\frac{\left(c-\frac{n^{\omega}}{\omega}\right)^{1-\sigma}}{1-\sigma}
$$

where $\sigma$ and $\omega$ govern risk aversion and the wage elasticity of labor supply, respectively.

The production function is given by

$$
z F(n) \text { with } F(n)=n^{\alpha}
$$

We assume that TFP shocks $(z)$ follow an $\mathrm{AR}(1)$ process given by:

$$
\log \left(z_{t+1}\right)=\rho_{z} \log \left(z_{t}\right)+\nu_{z, t+1}
$$

where $\nu_{z} \sim N\left(0, \sigma_{z}\right)$.

The potential bank capital shocks are assumed to take values that are between 0 and $\bar{\varepsilon}$, and have a cumulative distribution function

$$
F_{\sigma_{\varepsilon}}(\varepsilon)=\frac{1-\exp (\varepsilon)^{-\sigma_{\varepsilon}}}{1-\exp (\bar{\varepsilon})^{-\sigma_{\varepsilon}}},
$$

which is a transformation of the bounded Pareto distribution. The shape parameter, $\sigma_{\varepsilon}$, determines the variance of the $\varepsilon$ shocks. 


\subsection{Calibration}

A period in the model is assumed to be a year. Table 1 presents the parameter values. Appendix B has details of the data we use to guide our calibration and Appendix D provides details of the numerical solution.

Table 1: Parameters

\begin{tabular}{lcc}
\hline Parameters & Values & Target/Source \\
\hline Household discount factor, $\beta$ & 0.81 & Default probability: 0.5 percent \\
Risk aversion, $\sigma$ & 2 & Sosa-Padilla (2018) \\
Frisch elasticity, $\frac{1}{\omega-1}$ & 0.67 & Sosa-Padilla (2018) \\
Government spending, $g$ & 0.15 & Gov't consumption (percent GDP): 19.1 \\
Prob. of financial redemption, $\theta$ & 0.50 & Expected exclusion: 2 years \\
\hline Bankers' discount factor, $\delta$ & 0.96 & Real interest rate: 4 percent \\
Baseline bank capital, $\bar{A}$ & 0.28 & Bailouts in banking crises (percent GDP): 1.7 \\
Bank capital shock shape, $\sigma_{\varepsilon}$ & 4.26 & Standard deviation of output: 3.4 percent \\
Prob. of banking shock, $\pi$ & 0.03 & Banking crisis frequency: 1.8 percent \\
\hline Labor share, $\alpha$ & 0.70 & Sosa-Padilla (2018) \\
Working capital constraint, $\gamma$ & 0.52 & Sosa-Padilla (2018) \\
TFP shock persistence, $\rho_{z}$ & 0.80 & Standard value \\
TFP shock std, $\sigma_{z}$ & 0.02 & Standard value \\
\hline
\end{tabular}

The household and government's discount factor is set to 0.81 to match a default probability of 0.5 percent. Since our analysis mainly focuses on the European periphery, our target default probability of 0.5 percent is lower than that used for emerging economies (Aguiar, Chatterjee, Cole and Stangebye 2016) and higher than that for advanced economies (Hur, Kondo and Perri 2018). ${ }^{7}$ Government spending, $g$, is set to 0.15 to match the median government consumption share of GDP of 19.1 percent in GIIPS (1999-2019). The probability of financial redemption, $\theta$, is set to 0.5 , which implies an average exclusion of 2 years. ${ }^{8}$

The bank's discount factor is set to 0.96 , to be consistent with a real interest rate of 4 percent. The level of the baseline bank capital, $\bar{A}$, is set to 0.28 so that the model matches the size of bailouts during banking crises, which approximates 1.7 percent of GDP as shown

\footnotetext{
${ }^{7}$ The default frequency calculated for a panel of 38 advanced and emerging economies during 1970-2017 is 0.5 percent.

${ }^{8}$ This is a middle ground estimate given the long exclusion spells typically observed after defaults in emerging economies and the relative quick resolution of recent sovereign crises in peripheral Europe. In Appendix C, Table C.7 shows the sensitivity analysis for $\theta$.
} 
in the empirical section. The shape parameter for shocks to bank capital, $\sigma_{\varepsilon}$, is set to 4.26 to generate a standard deviation of output that matches the median of 3.4 percent among GIIPS. The parameter that governs the probability of shocks to banks' capital, $\pi$, is set to 0.03 so that the model matches the banking crisis frequency of 1.8 percent in a panel of 38 advanced and emerging economies from 1970 to $2017 .^{9}$

Six parameters are set externally. Following Sosa-Padilla (2018), we set risk aversion, $\sigma=2$, and set the value of $\omega$ to correspond to a Frisch elasticity of 0.67 , both standard values in the literature. Also as in Sosa-Padilla (2018), we set the labor income share $\alpha=0.7$ and the working capital constraint $\gamma=0.52$. Finally, we set the persistence $\rho_{z}=0.8$ and standard deviation $\sigma_{z}=0.02$, within the range of the typical values used in the literature. ${ }^{10}$ Appendix $\mathrm{C}$ presents a sensitivity analysis and shows that our main results are robust to using alternative values for some key model parameters.

\subsection{External validity: simulated moments}

In this subsection, we examine the fit of the model. Table 2 shows the targeted and untargeted moments from our model simulations and their data counterparts. As is usual in this literature, we report statistics for periods in which the government has access to financial markets and no defaults are declared (the only exception is default frequency, for which we use all simulation periods).

The model generates spreads that behave reasonably well. The mean and the volatility of the spread are lower than in the data. ${ }^{11}$ This is not surprising as the Global Financial Crisis and the European Sovereign Debt crises occured during the period. The model also generates countercylical spreads, qualitatively consistent with the data, albeit less so than in the data. The mean debt level in the model simulations is 15.5 percent of GDP, below

\footnotetext{
${ }^{9}$ In the data, we follow the classification in Laeven and Valencia (2013), who use banking sector losses and other indicators to identify banking crises. The list of 38 advanced and emerging economies is as in Davis, Mack, Phoa and Vandenabeele (2016). In the model, we define a banking crisis as a non-zero reduction of bank's capital. This occurs with probability $\pi\left(1-F_{\sigma_{\varepsilon}}(\underline{\varepsilon})\right)$ where $\underline{\varepsilon}$ refers to the lowest non-zero value in our discrete grid for $\varepsilon$.

${ }^{10}$ Previous works on sovereign default with production have parameterized the productivity process in a similar way. For example, Boz et al. (2014) (in a calibration for Spain) estimate the TFP's autocorrelation to be .54 and impose a standard deviation of 2.6\%; Hatchondo, Martinez and Roch (2020) (also calibrated to Spanish data) find annualized persistence and standard deviation estimates of .89 and $2 \%$, respectively. Our parameterization of the TFP process (representative of GIIPS) is within these estimates.

${ }^{11}$ In the model, we compute sovereign spreads in our simulations as the difference between the bond's yield $(1 / q)$ and the real rate implied by the banker's discount factor $(1 / \delta)$. In the data, the spread is computed as the nominal interest rate on government bonds in GIIPS minus that of Germany, from 1999 to 2019.
} 
Table 2: Simulated moments: model and data

\begin{tabular}{lcc}
\hline & Model & Data \\
\hline Default frequency & 0.5 & 0.5 \\
Banking crisis frequency & 1.8 & 1.8 \\
Gov't spending/GDP & 19.1 & 19.1 \\
Bailouts/GDP (banking crisis) & 1.7 & 1.7 \\
\hline Sovereign spread & & \\
mean & 0.7 & 1.2 \\
standard deviation & 0.6 & 1.8 \\
corr(spread,output) & -0.3 & -0.7 \\
Debt/GDP & 15.5 & 25.8 \\
\hline
\end{tabular}

Units: percent. Both the standard deviation and the correlation are calculated based on HP-filtered residuals.

the median domestic government debt/GDP in EU countries, 25.8 percent. ${ }^{12}$ Accounting for more than 50 percent of this untargeted moment is a reasonably good fit, given the wellknown difficulty of sovereign default models with one-period debt in producing sizeable debt ratios at the observed default frequencies. ${ }^{13}$

Table 3 shows that, conditional on experiencing a banking crisis in the previous year, the default probability is 0.2 percentage points higher than the unconditional default frequency of 0.5 percent. This increase in the default probability is the 'diabolic loop' at work: Banking crises trigger payments of contingent bailouts, and therefore imply that governments need to borrow more. This higher level of indebtedness pushes governments into the default risk zone, leading to more frequent defaults.

These 'diabolic loop' dynamics naturally translate into sovereign spreads. The unconditional mean spread is 0.7 percent, but conditional on observing a banking crisis, the mean spread increases by 0.2 percentage points. This increase reflects not only the higher likelihood of default, but also a decline in the 'lending discount'. If there is a banking crisis in period $t$, then a default is more likely in period $t+1$ and, hence, the lender charges a higher default premium. Additionally, if in $t+1$ the default is averted, then the interest rate on

\footnotetext{
${ }^{12}$ This median for domestic government debt is obtained using ECB data for the period 1999-2019 (including debt at all original maturities). It includes all EU countries except for the UK, Greece, Ireland and Latvia due to missing data.

${ }^{13}$ The literature has dealt with this shortcoming in different ways. One example is D'Erasmo and Mendoza (2020) who study optimal domestic and external default using a one-period debt model calibrated to European data. They create a maturity-adjusted debt-to-GDP ratio and report it to be 7.45 percent of GDP. A different approach (e.g., Arellano, 2008) is to target the debt service instead of debt stock. We focus on domestic debt since we model a closed economy.
} 
Table 3: Simulated moments: unconditional and banking crisis

\begin{tabular}{lcc}
\hline & Unconditional & Banking crisis \\
\hline Default frequency & 0.5 & 0.7 \\
Sovereign spread & & \\
mean & 0.7 & 0.9 \\
standard deviation & 0.6 & 1.0 \\
Debt/GDP & 15.5 & 16.0 \\
Bailout/GDP & 0.9 & 1.7 \\
\hline
\end{tabular}

Units: percent. The standard deviation is calculated based on HPfiltered residuals of the spread.

loans is lower: There is higher debt and therefore greater loan market liquidity. Thus, the sovereign bond becomes a less attractive investment for these two reasons: lower probability of repayment and, in case of repayment, lower overall return. Our simulations also generate higher spread volatility conditional on a banking crisis because the risk of default increases.

The last row of Table 3 shows that, on average, the model features larger contingent bailouts during banking crises than unconditionally. ${ }^{14}$ This is a distinctive feature of the data, as we documented in Figure 1.

\subsection{External validity: dynamics around banking crises}

To further validate our model, we examine the behavior of output and sovereign yields around banking crises. To compute the data counterparts, we construct an annual dataset of real interest rates, GDP, government debt, and banking crisis indicators for the years 1950-2016, using the Jordà, Schularick and Taylor (2017) Macrohistory database. ${ }^{15}$

Absent government intervention, a banking crisis reduces loanable funds, increases the firms' borrowing costs and decreases output. At the same time, the government can issue contingent guarantees to prop up the supply of loans and mitigate the negative effects of the shocks to bank capital. Therefore, the equilibrium response of output depends on the initial debt level: governments with more debt (less fiscal space) face limits on the amount of bank capital losses that can be guaranteed and will, therefore, experience a larger output contraction. Figure 2 shows that this model prediction also holds qualitatively in the data. Moreover, both model and data show that banking crises occurring at high debt levels are

\footnotetext{
${ }^{14}$ Consistent with the data, here we are reporting announced bailouts (as a percent of GDP), regardless of whether a banking crisis materializes and bailout transfers are disbursed.

${ }^{15}$ See Appendix B for details regarding the construction of the dataset.
} 
Figure 2: Output around banking crises

Data

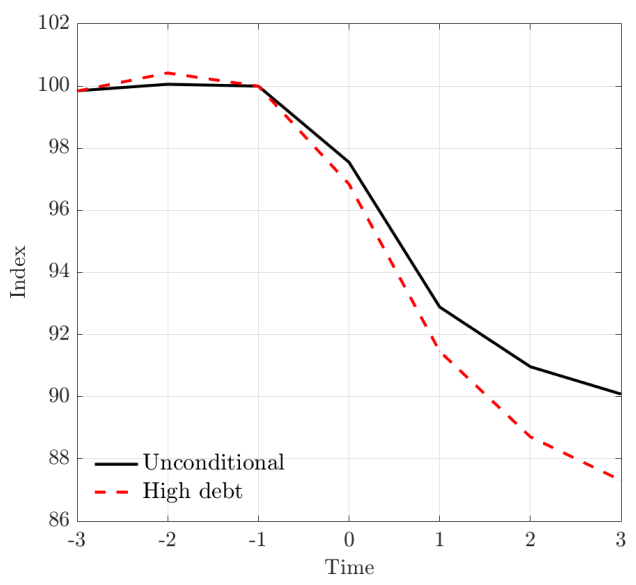

Model

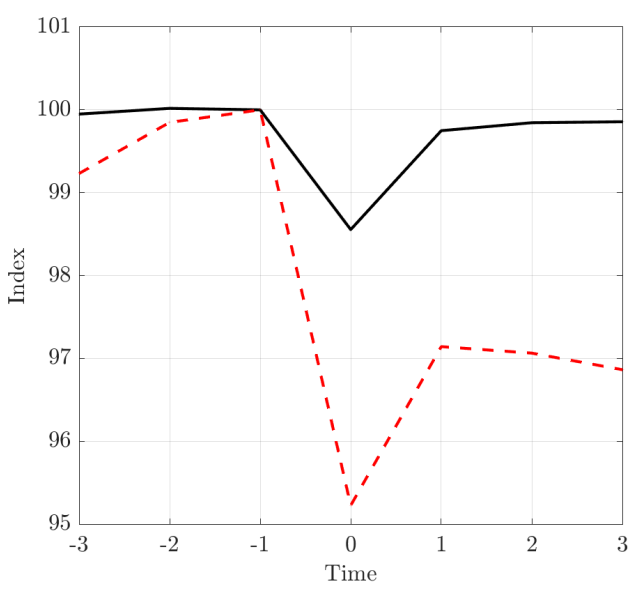

Note: The left and right panels show the dynamics of GDP around banking crises in the data and in the model, respectively. The red dashed line conditions on high debt (above the 75th percentile). All series in this figure are normalized to 100 in $t=-1$.

characterized by protracted output declines. In the model this happens for three interrelated reasons: (i) mean reversion in productivity, (ii) worsening borrowing conditions and deleveraging, and (iii) higher distortionary taxes. In this class of models, the samples identified as 'high-debt' samples are those where the economy experiences a series of good productivity realizations, which allow it to take on higher debt. This eventually is followed by a mean reversion in TFP, contributing to a decline in output. At the same time, deteriorating productivity worsens borrowing terms, to which the government responds by deleveraging. This deleveraging translates into lower liquidity in the domestic credit markets in subsequent periods, further contributing to a decline in output. Finally, to finance this deleveraging, the government raises distortionary taxes, which depresses equilibrium labor and output. These model dynamics for debt and taxes are illustrated in Figure 3.

Furthermore, our theory predicts an increase in sovereign yields during banking crises. Figure 4 shows that this model prediction is qualitatively consistent with the data. We also see that, both in the model and in the data, when the government suffers a banking crisis with high debt levels, sovereign yields are higher. For the same reasons highlighted above, the high-debt government faces worse borrowing terms, forcing it to deleverage and increase distortionary taxes. Because the government does not want to distort the economy further, it chooses to accept higher equilibrium yields instead of deleveraging even more. 
Figure 3: Debt and taxes around banking crises

\section{Debt/GDP}

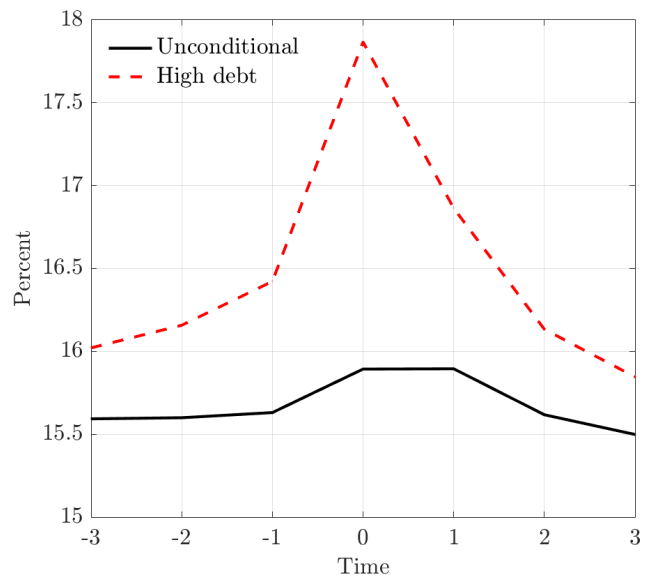

Tax rate

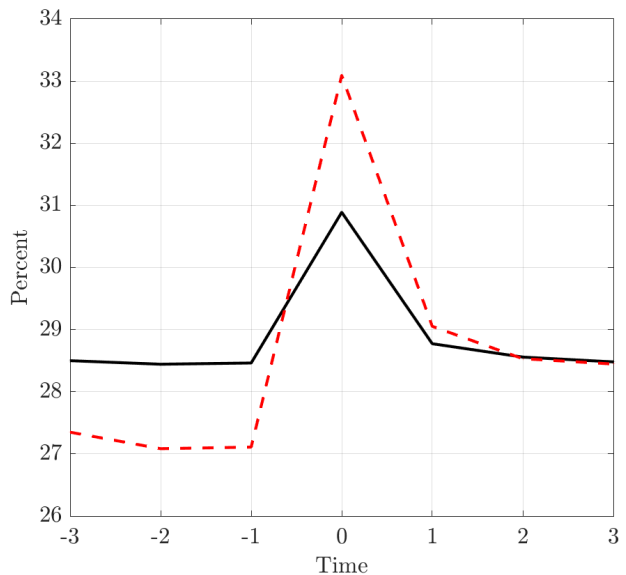

Note: The left panel shows the dynamics of Debt/GDP around banking crises and the right panel shows the dynamics of the tax rate. Both panels are for model-generated data. The red dashed line conditions on high debt (above the 75 th percentile).

Figure 4: Sovereign yields around banking crises

Data

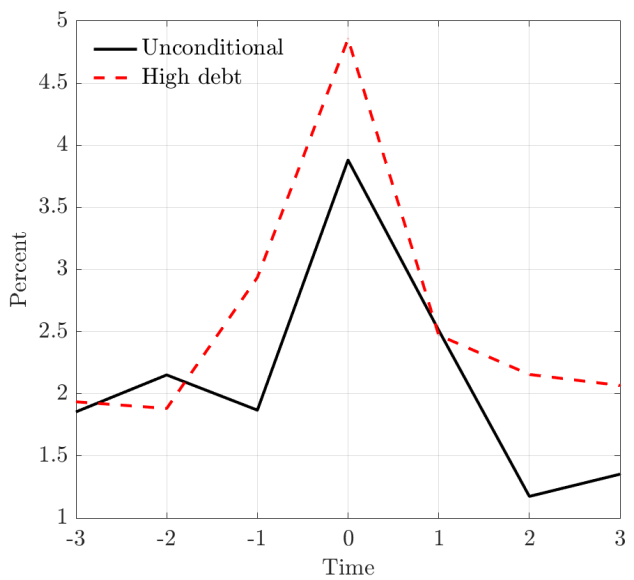

Model

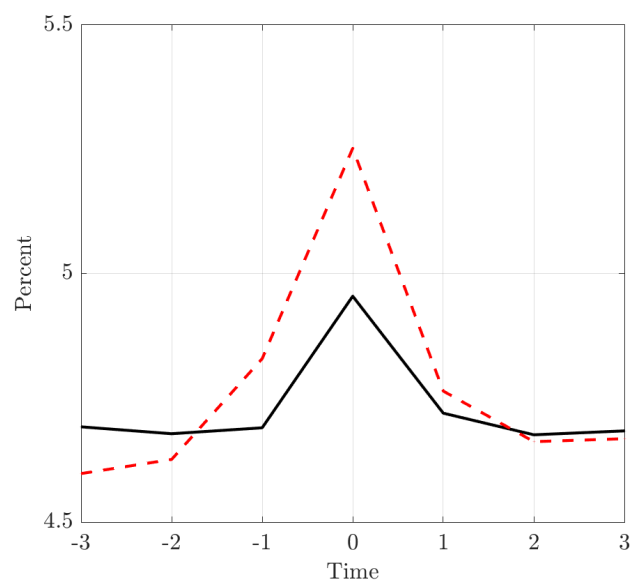

Note: The left and right panels show the dynamics of sovereign yields around banking crises in the data and in the model, respectively. The red dashed line conditions on high debt (above the 75th percentile). 


\subsection{Properties of optimal policies}

Default incentives, bond prices, and debt dynamics. Our model features a rich interaction between debt levels, default incentives, banking crises, and optimal bailout guarantees. Consistent with the default literature, our model also generates default incentives that decrease with the aggregate level of productivity and increase with debt, which can be verified in the left panel of Figure 5. In addition to this standard finding, we also see that the default set shrinks with higher values of the bank capital shock. This is because severe banking crises can lead to sharp contractions in output absent government bailouts, thus increasing the cost of default.

The price schedule (right-panel of Figure 5) reflects these default incentives. As usual, higher realizations of productivity are associated with better prices (and higher debt capacity). The price schedule demonstrates that borrowing is essentially risk-free for debt ratios below 12 percent. Consequently, starting from zero debt, the economy's debt-to-GDP ratio quickly increases until it reaches 12 percent. It then 'lives' in the region where default risk is small but positive, as in Figure 6, which plots the histograms of debt-to-GDP ratios both unconditionally and conditional on banking crises. Since the left tails of these histograms are very long, we choose to truncate them in our plots.

Figure 5: Default sets and bond prices
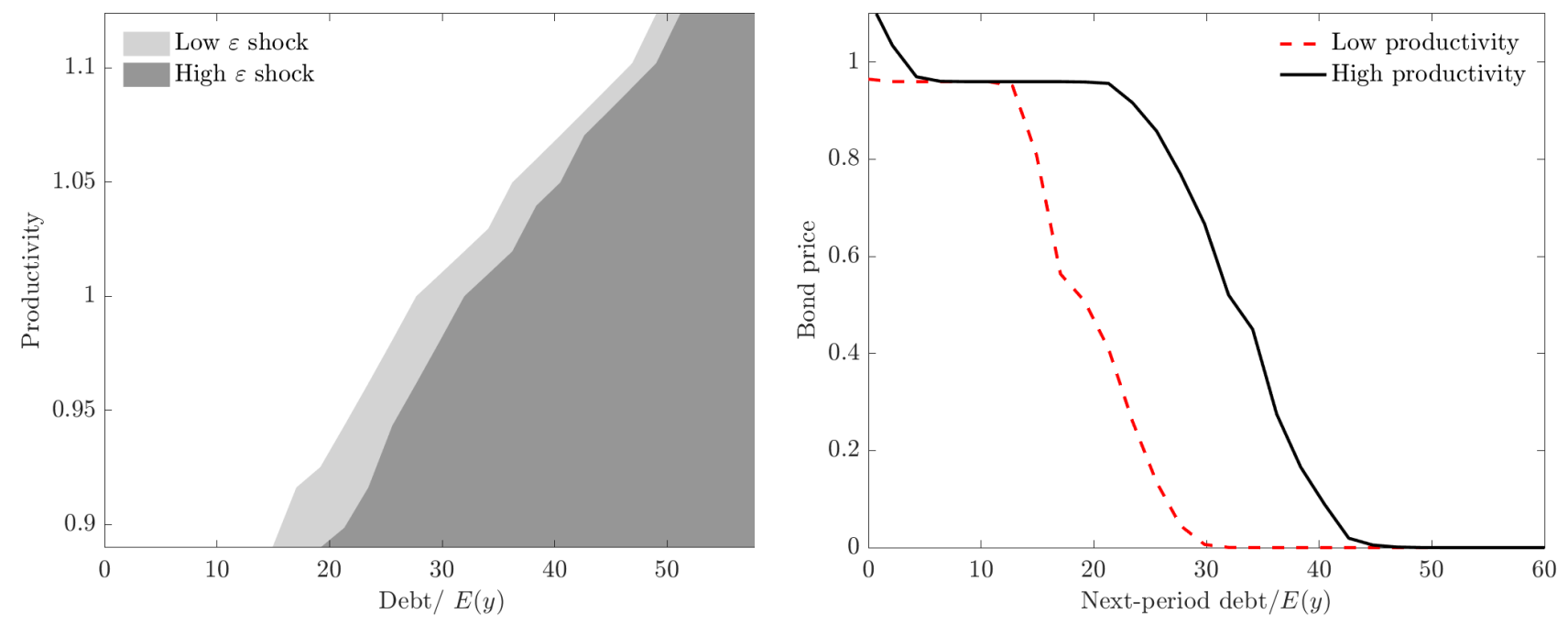

Note: The left panel shows the default sets with the shaded areas indicating default and the white area indicating repayment. The right panel shows the equilibrium bond price schedule.

Figure 6 also shows that the debt-to-GDP distribution conditional on a banking crisis is 
more skewed to the left than the unconditional distribution. Thus, not only do banking crises lead to a higher average debt-to-GDP ratio (Table 3), but they also increase the probability of observing high debt-to-GDP realizations (greater than 20 percent), reinforcing the 'diabolic loop' dynamics.

Figure 6: Conditional and unconditional debt distributions

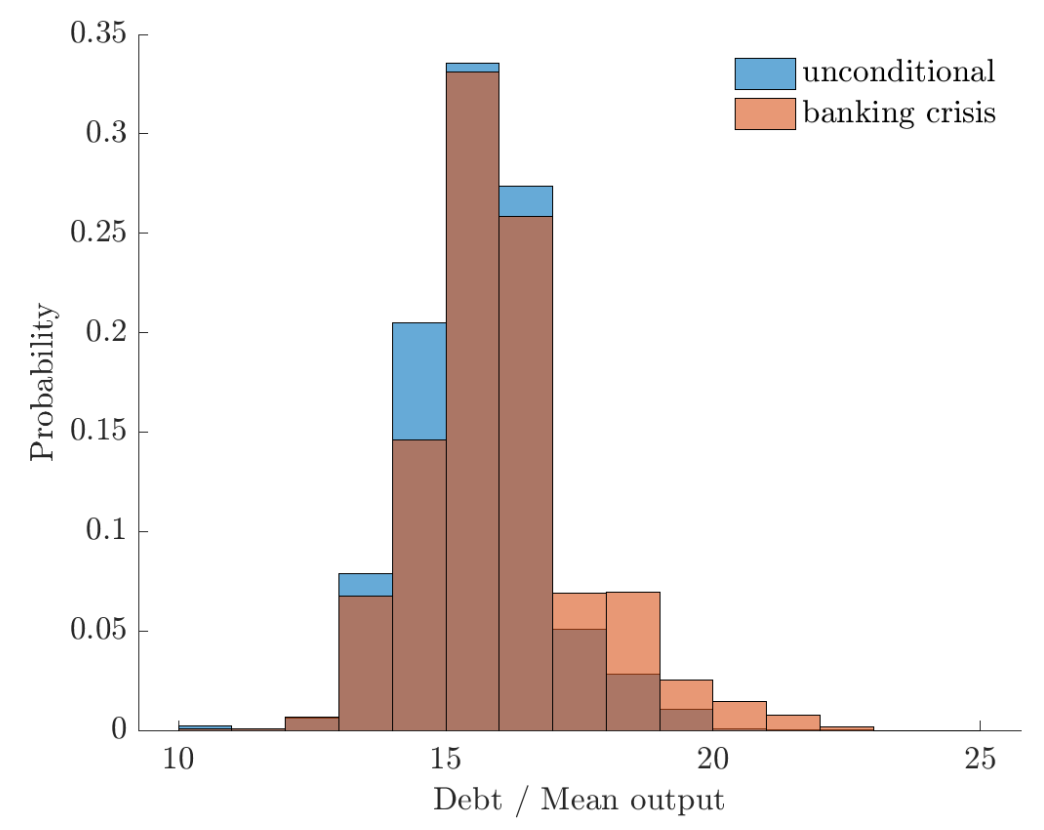

Optimal bailout policies. The ability of the government to issue bailouts depends on the state of the economy in terms of productivity $(z)$ and potential losses to bank capital $(\varepsilon)$, in addition to the existing level of debt $(B)$. Here we examine the bailout policy functions generated by our model to highlight the role of each of these factors. Figure 7 shows the bailout policy functions expressed as the percent of the potential loss that the government promises to guarantee. Inspecting both panels of this figure, we find the following properties for the bailouts: 
Figure 7: Bailout policy
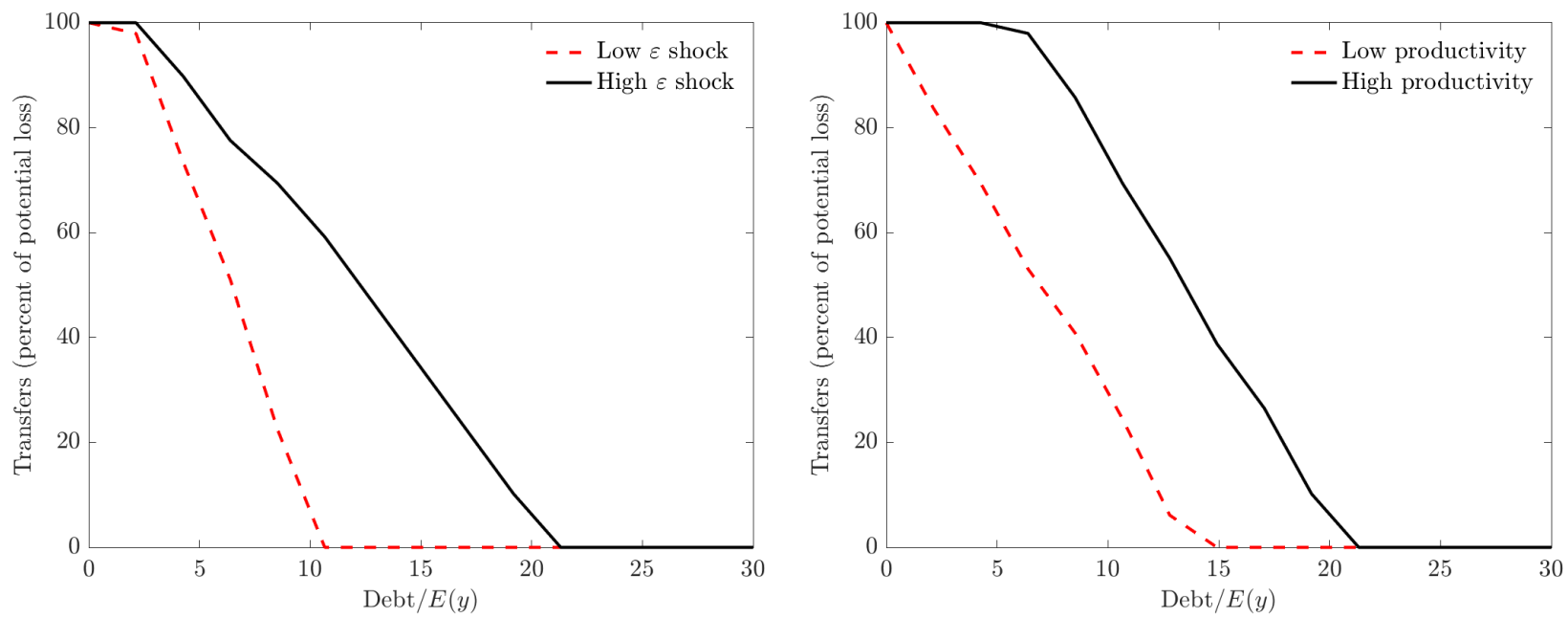

Note: The panels show the bailout policy functions expressed as the percent of the potential loss that the government promises to guarantee (i.e. $100 \times T(B, s, A) /(\bar{A} \varepsilon))$.

1. Increasing in $\varepsilon$. As the potential loss to bank capital increases, the proportional bailout the government chooses grows larger. This is because the impact of financial shocks on the economy are non-linear. As can be seen in equation (17), absent government bailouts, higher values of $\varepsilon$ have a disproportionately larger effect on $r$ than lower values of $\varepsilon$ (i.e., $\varepsilon$ affects $r$ in a convex manner). Thus, the government uses bailout transfers to affect the supply side of the loans' market, keeping the equilibrium interest rate low, especially when the financial shocks are large.

2. Decreasing in $B$. While bailout guarantees play an essential role alleviating the effects of banking crises on the real sector by boosting liquidity, increased default risk makes it more difficult for government to provide transfers as the debt level rises. This is because when the banking crisis occurs, the bailouts will need to be financed with more borrowing. Therefore, the greater the stock of initial debt, the less fiscal space the government has to extend asset guarantees.

3. Increasing in $z$. This intuitive property is due to two forces that move in the same direction. First, with greater productivity, credit becomes more valuable. Therefore, it makes sense for the government to extend larger guarantees in good times. Second, the cost of borrowing necessary to finance a bailout is lower during periods of high productivity. Given the persistence of productivity shocks, a high productivity shock during this period increases the likelihood of a high productivity shock in the 
subsequent period, leading to lower default risk, better prices for the government, and greater borrowing capacity to finance the bailout transfers.

\section{On the Optimality of Bailouts}

As explained in the previous section, bailouts come with a trade-off. They allow the government to boost liquidity and output during banking crises but they also increase debt and default risk (i.e., there is a 'diabolic-loop'). Having described the properties of our model and the equilibrium bailout policies, we proceed to ask: Are bailouts desirable?

To answer this normative question, we proceed in two steps. First, we solve a no-bailouts version of our model and compare its simulated moments to those in the baseline model. We find that the model without bailouts features fewer defaults and lower spreads, while sustaining higher levels of debt relative to the model with bailouts. This suggests that, from an ex ante perspective, allowing bailouts may not be optimal. Thus, as a second step, we solve for alternative versions of the model in which bailouts are allowed but are restricted in size, nesting both the baseline (with unrestricted bailouts) and the no-bailouts models. We find that when initial debt is very low, governments prefer unrestricted access to bailouts. However, when governments begin with moderate to high debt level, banning bailouts altogether is beneficial. We find these results remarkable since our analysis abstracts from moral hazard concerns, a well-studied reason for which bailouts might be undesirable from an ex ante perspective. We show that the welfare consequences are large.

Table 4 reports simulated moments for the baseline and the no-bailouts versions of our model. As previously mentioned, the baseline economy exhibits higher default risk, higher and more volatile spreads, and a lower debt-to-GDP ratio. These statistics reflect that the baseline economy faces inferior borrowing circumstances: It can sustain less debt at higher rates. On the other hand, the lending rate (between banks and firms) is lower in the baseline economy because bailouts increase liquidity and improve borrowing terms for firms. Consequently, output falls less in bad times, explaining the (slightly) lower countercyclicality

of spreads when bailouts are possible. Overall, the trade-off induced by bailouts is clearly captured by these business cycle dynamics. 
Table 4: Simulated moments comparison

\begin{tabular}{lcc}
\hline & Baseline model & Model without bailouts \\
\hline Default frequency & $0.5^{*}$ & 0.3 \\
Sovereign spread & & \\
mean & 0.7 & 0.5 \\
standard deviation & 0.7 & 0.5 \\
corr(GDP, spread) & -0.2 & -0.3 \\
Debt/GDP & 15.5 & 26.8 \\
Mean lending rate & 0.0 & 0.2 \\
\hline
\end{tabular}

Units: percent. ${ }^{*}$ denotes targeted moments.

We next examine, from an ex ante perspective, what restrictions, if any, a country should optimally impose on the size of the bailouts. To do so, we modify the constraint on $T(B, s, A)$ as follows:

$$
\left.\left.\begin{array}{cl}
T=0 & \text { if } A=\bar{A} \\
0 \leq T \leq \min \{\varepsilon \bar{A}, \phi \bar{\varepsilon} \bar{A}\} & \text { if } A=(1-\varepsilon) \bar{A}
\end{array}\right\} \quad \text { (new constraint on } T\right)
$$

where $\bar{\varepsilon} \bar{A}$ corresponds to the largest possible financial shock and $\phi \in[0,1]$. Setting $\phi=0$ corresponds to the model with no bailouts and $\phi=1$ corresponds to the baseline model.

With this modified framework, we compute the ex ante welfare-maximizing levels of $\phi$ for different levels of initial debt, $B_{0}$. First, we solve for $\Lambda\left(B_{0} ; \phi\right)$, the permanent increase in consumption needed in the no-bailouts economy to make households indifferent between this economy and another with $\phi>0$. Formally, $\Lambda\left(B_{0} ; \phi\right)$ is implicitly defined by

$$
\mathbb{E}_{s} V_{\Lambda}\left(B_{0}, s ; 0\right)=\mathbb{E}_{s} V\left(B_{0}, s ; \phi\right)
$$

where the expectation taken over the ergodic distribution over $s=\{z, \varepsilon\}$ and $V_{\Lambda}\left(B_{0}, s ; 0\right)$ is the value resulting from a permanent increase in consumption $\Lambda$ in the economy with no bailouts. Second, for each level of initial debt, we compute the welfare maximizing value of $\phi$.

Figure 8 shows three regions. For very low levels of initial debt, the economy is better off with unrestricted bailouts $(\phi=1)$ - that is, it is optimal to allow the government to issue bailouts that can fully cover even the largest shocks to bank capital. For intermediate debt levels, it is optimal to restrict considerably the governments' ability to issue bailouts. Finally, for debt levels exceeding 13 percent of mean output it is welfare increasing to set 
$\phi=0$ - banning the government from issuing bailouts. What are the welfare consequences of instituting the optimal restrictions on bailouts? When a government's initial debt-to-GDP levels exceed 13 percent, access to unrestricted bailouts result in a 1.5 percent welfare loss relative to no bailouts, a large welfare consequence.

Figure 8: Optimal bailout restrictions

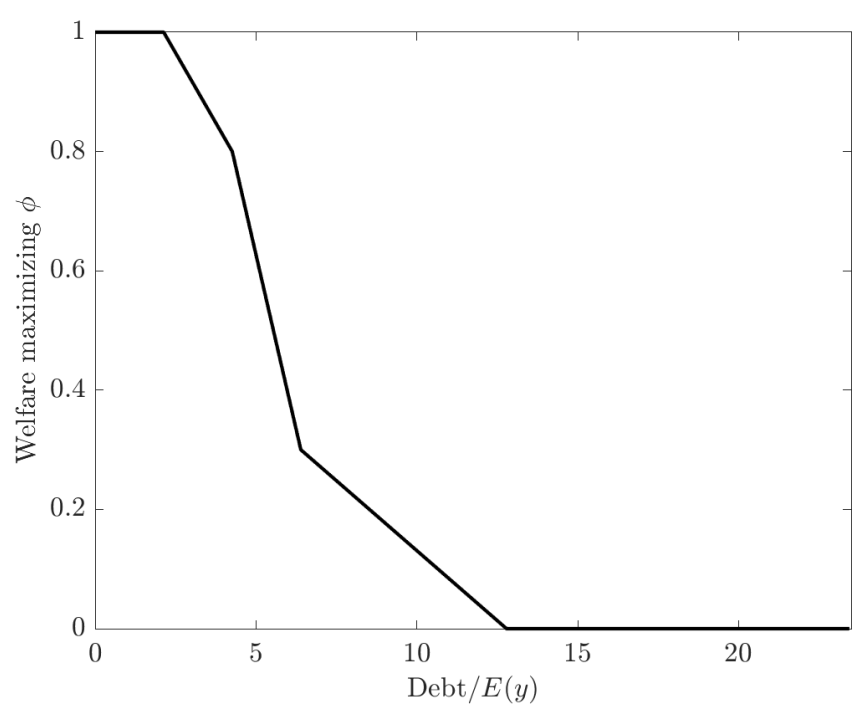

In summary, the results in this section indicate that for the mean debt level in our simulations (15 percent of GDP), the economy will be better off if the government cannot issue bailouts. This is a strong result considering that our framework has (i) a benevolent government and (ii) a bailout policy that does not trigger moral hazard concerns. Overall, our results highlight the negative effects of the sovereign-bank nexus (i.e., the 'diabolic loop').

\section{Conclusion}

We study the dynamic relationship between sovereign defaults, banking crises, and government bailouts. We first document that when governments intervene to help distressed banking sectors, contingent guarantees are the most prevalent form of intervention.

We then build and solve a general equilibrium model of sovereign default, in which there is a benevolent government that maximizes household welfare by choosing debt, defaults, distortionary taxes, and bank bailouts. The economy is subject to two types of aggregate uncertainty - shocks to firm productivity and shocks to banks' capital. In anticipation of an adverse banking shock, banks reduce lending to the private sector. The sovereign may choose to announce guarantees (i.e. conditional transfers) to compensate for the banks' 
capital losses in the event of a crisis - a bailout. Sovereign defaults are costly because it leads to a deterioration of bank balance sheets. Moreover, during default episodes, the government temporarily loses access to debt financing and with it the ability to issue bailouts. As a consequence, banks' credit to the private sector declines, and eventually output and consumption fall. The benefit of a default is that all existing debt is wiped out, relaxing the government's budget constraint, and allowing it to reduce distortionary taxes. Our framework is flexible enough to feature defaults that lead to a decline in the health of the banking sector and vice versa: a complete 'doom loop.'

Using the calibrated model, we show that the occurrence of a banking crisis increases the default probability by 0.2 percentage points (from 0.5 to 0.7 percent annually) and raises the level and volatility of sovereign spreads (the latter increases from 0.6 to 1.0 percent). In the model, the government issues contingent guarantees that exhibit clear properties. Other things equal, they are: (i) decreasing in the level of government debt, since the more debt it has, the less fiscal space the government has to prop up banking sector assets; (ii) increasing in aggregate productivity, since the better the aggregate state of the economy, the greater the value of credit and the cheaper it is to borrow to provide the guarantees; and (iii) increasing with the severity of the banking crisis, because the effects of financial shocks are nonlinear. Small shocks have negligible impacts on loans to the private sector, whereas large shocks can lead to severe contractionary credit crunches in the absence of government interventions.

Even though bailouts are useful to mitigate the adverse effects of banking crises, we find that from an ex ante perspective, the country is better off without bailouts. Since bailouts are financed with higher government debt, which increases spreads and may trigger defaults, they create a 'diabolic loop.' 


\section{References}

Abad, Jorge, "Breaking the Sovereign-Bank Nexus," CEMFI Working Paper, 2019.

Acharya, Viral, Itamar Drechsler, and Philipp Schnabl, "A pyrrhic victory? Bank bailouts and sovereign credit risk," The Journal of Finance, 2014, 69 (6), 2689-2739.

Aguiar, Mark and Gita Gopinath, "Defaultable debt, interest rates and the current account," Journal of international Economics, 2006, 69 (1), 64-83.

Aguiar, Mark, Satyajit Chatterjee, Harold Cole, and Zachary Stangebye, "Quantitative models of sovereign debt crises," in "Handbook of Macroeconomics," Vol. 2, Elsevier, 2016, pp. 1697-1755.

Arce, Fernando, "Private Overborrowing under Sovereign Risk," Technical Report 2020.

Arellano, Cristina, "Default risk and income fluctuations in emerging economies," The American Economic Review, 2008, pp. 690-712.

Azzimonti, Marina and Vincenzo Quadrini, "International Spillovers and Bailouts," Technical Report 2019.

Balloch, Cynthia Mai, "Default, Commitment, and Domestic Bank Holdings of Sovereign Debt," 2016. Mimeo, Columbia University.

Balteanu, Irina, Aitor Erce, and Laura Fernandez, "Bank crises and sovereign defaults: Exploring the links," Bank of Spain, 2011.

Bianchi, Javier, "Efficient bailouts?," American Economic Review, 2016, 106 (12), 360759.

Bocola, Luigi, "The pass-through of sovereign risk," Journal of Political Economy, 2016, $124(4), 879-926$.

Bolton, Patrick and Olivier Jeanne, "Sovereign default risk and bank fragility in financially integrated economies," IMF Economic Review, 2011, 59 (2), 162-194.

Borensztein, Eduardo and Ugo Panizza, "The costs of sovereign default," IMF Staff Papers, 2009, 56 (4), 683-741.

Boz, Emine, Pablo D'Erasmo, and Bora Durdu, "Sovereign risk and bank balance sheets: The role of macroprudential policies," Manuscript, International Monetary Fund, 2014.

Brunnermeier, Markus K, Sam Langfield, Marco Pagano, Ricardo Reis, Stijn Van Nieuwerburgh, and Dimitri Vayanos, "ESBies: Safety in the tranches," Economic Policy, 2017, 32 (90), 175-219. 
Capponi, Agostino, Felix C Corell, and Joseph E Stiglitz, "Optimal Bailouts and the Doom Loop with a Financial Network," Technical Report, National Bureau of Economic Research 2020.

Cooper, Russell and Kalin Nikolov, "Government debt and banking fragility: The spreading of strategic uncertainty," International Economic Review, 2018, 59 (4), 19051925.

Davis, J Scott, Adrienne Mack, Wesley Phoa, and Anne Vandenabeele, "Credit booms, banking crises, and the current account," Journal of International Money and Finance, 2016, 60, 360-377.

De Ferra, Sergio and Enrico Mallucci, "Avoiding Sovereign Default Contagion: A Normative Analysis," Federal Reserve Board of Governors Working Paper, 2020.

D'Erasmo, Pablo and Enrique G Mendoza, "History remembered: Optimal sovereign default on domestic and external debt," Journal of Monetary Economics, 2020.

Eaton, Jonathan and Mark Gersovitz, "Debt with potential repudiation: Theoretical and empirical analysis," Review of Economic Studies, 1981, 48 (2), 289-309.

Farhi, Emmanuel and Jean Tirole, "Deadly embrace: Sovereign and financial balance sheets doom loops," The Review of Economic Studies, 2018, 85 (3), 1781-1823.

Favero, Carlo and Alessandro Missale, "Sovereign spreads in the eurozone: which prospects for a Eurobond?," Economic Policy, 2012, 27 (70), 231-273.

Gaballo, Gaetano and Ariel Zetlin-Jones, "Bailouts, moral hazard and banks' home bias for Sovereign debt," Journal of Monetary Economics, 2016, 81, 70-85.

Gennaioli, Nicola, Alberto Martin, and Stefano Rossi, "Sovereign default, domestic banks, and financial institutions," The Journal of Finance, 2014, 69 (2), 819-866.

Gennaioli, Nicola, Alberto Martin, and Stefano Rossi, "Banks, government bonds, and default: What do the data say?," Journal of Monetary Economics, 2018, 98, 98-113.

Gourinchas, Pierre-Olivier, Philippe Martin, and Todd Messer, "The economics of sovereign debt, bailouts and the Eurozone crisis," 2020.

Gunn, Christopher M. and Alok Johri, "Financial news, banks, and business cycles," Macroeconomic Dynamics, 03 2018, 22 (2), 173-198.

Guo, Si and Yun Pei, "The Impact of Sovereign Default on Lending Countries," Mimeo, 2020.

Hatchondo, Juan Carlos, Leonardo Martinez, and Francisco Roch, "Fiscal rules and the Sovereign Default Premium," IMF Working Paper, 2020.

Hur, Sewon, Illenin Kondo, and Fabrizio Perri, "Real interest rates, inflation, and default," Technical Report 2018. 
Jordà, Òscar, Moritz Schularick, and Alan M Taylor, "Macrofinancial history and the new business cycle facts," NBER macroeconomics annual, 2017, 31 (1), 213-263.

Keister, Todd, "Bailouts and financial fragility," The Review of Economic Studies, 2016, $83(2), 704-736$.

Laeven, Luc and Fabian Valencia, "Systemic banking crises database," IMF Economic Review, 2013, 61 (2), 225-270.

Laeven, Luc and Fabian Valencia, "Systemic Banking Crises Database II," IMF Economic Review, 2020, pp. 1-55.

Mallucci, Enrico, "Domestic debt and sovereign defaults," FRB International Finance Discussion Paper, 2015, (1153).

Moretti, Matias, "The Asymmetric Pass-Through of Sovereign Risk," Technical Report 2020.

Niepmann, Friederike and Tim Schmidt-Eisenlohr, "Bank bailouts, international linkages, and cooperation," American Economic Journal: Economic Policy, 2013, 5 (4), 270305.

Pancrazi, Roberto, Hernán D Seoane, and Marija Vukotić, "Welfare gains of bailouts in a sovereign default model," Journal of Economic Dynamics and Control, 2020, p. 103867.

Perez, Diego J., "Sovereign Debt, Domestic Banks and the Provision of Public Liquidity," Technical Report 2015.

Reinhart, Carmen M, "This time is different chartbook: country histories on debt, default, and financial crises," Technical Report, National Bureau of Economic Research 2010.

Roch, Francisco and Harald Uhlig, "The dynamics of sovereign debt crises and bailouts," Journal of International Economics, 2018, 114, 1-13.

Sosa-Padilla, César, "Sovereign Defaults and Banking Crises," Journal of Monetary Economics, 2018, 99, 88-105.

Thaler, Dominik, "Sovereign default, domestic banks and exclusion from international capital markets," Technical Report 2018. 


\section{A Contingent Liabilities}

In this section, we consider a broader notion of contingent government interventions by looking at the changes in government contingent liabilities instead of government guarantees. In addition to government asset guarantees, the concept 'contingent liabilities' includes public-private partnerships (PPP) recorded off-balance sheet of the government and liabilities of government controlled entities classified outside of general government operations. For most countries, government guarantees make up the largest share in government contingent liabilities. Because contingent liabilities are also stocks, we calculate the annual change in contingent liabilities as a share of GDP, and take the average of that ratio across all countries.

Figure A.1: Government contingent liabilities and capital transfers

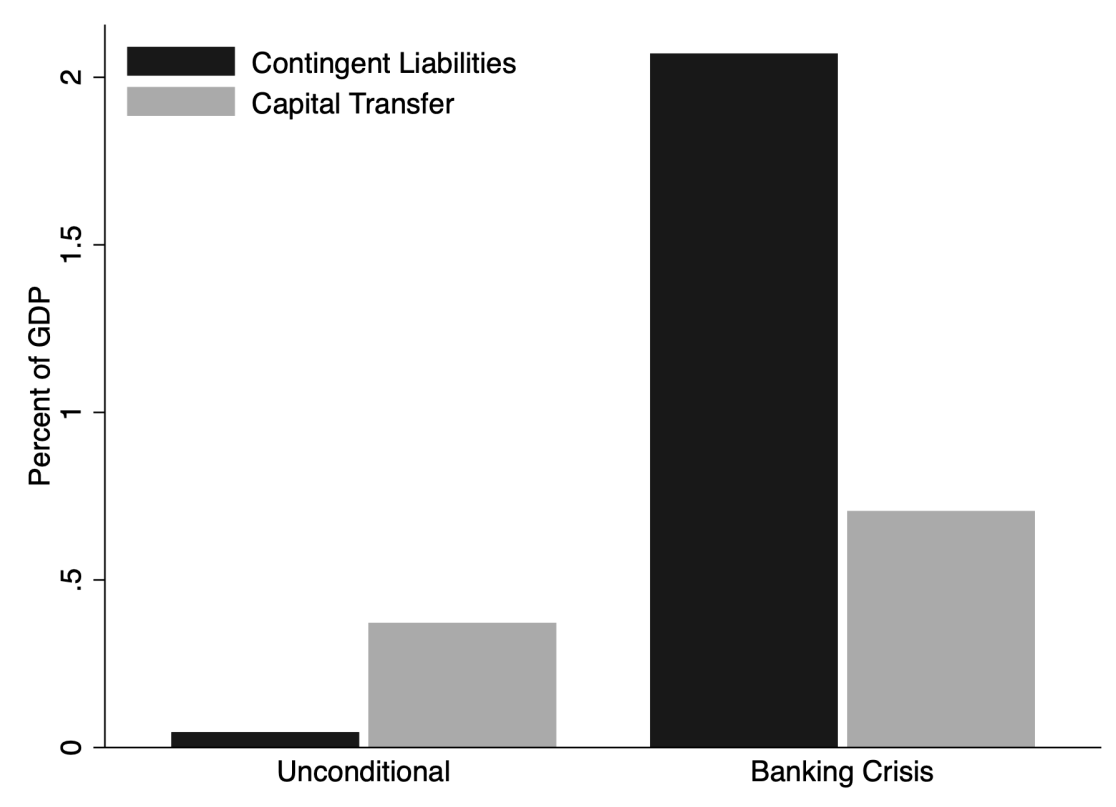

Figure A.1 shows a side-by-side comparison of contingent liabilities and capital transfers in the entire sample and conditional on banking crisis. We obtain a similar pattern as before: Contingent liabilities exceed 2 percent during banking crises and they are close to zero unconditionally. 


\section{B Data appendix}

\section{Data description for Figures 1 and A.1}

We obtain the data for government guarantees, contingent liabilities and capital transfers from Eurostat. We obtain these series for 23 countries, which are Austria, Belgium, Bulgaria, Croatia, Cyprus, Denmark, Finland, France, Germany, Greece, Hungary, Ireland, Italy, Latvia, Lithuania, Luxembourg, Portugal, Slovenia, Spain, Sweden, the Czech Republic, the Netherlands, and the United Kingdom. Our sample is limited by the data availability and it covers the years between 2007-2019. For each country, we calculate the first difference of government guarantees and contingent liabilities, and we divide them by the GDP series obtained from the World Bank Database to generate the plots. Next, we calculate the share of capital transfers in GDP for each country between 2007-2019. Using the banking crisis dates from Laeven and Valencia (2020) we create the sample conditional on banking crises.

\section{Data description for calibration}

We calculate the unconditional default frequency and default frequency conditional on banking crises using the crises dates given in Laeven and Valencia (2020). This dataset covers the years 1970-2017. The sample contains 21 advanced and 17 emerging market economies as in Davis et al. (2016). The unconditional default frequency is calculated as the total count of default events divided by the total number of country-year pairs.

The share of government spending in GDP is calculated using the data from OECD. Our sample consists of GIIPS during 1999-2019. First, for each country we calculate the average public consumption as a share of GDP and then compute the median across country averages.

We calculate the domestic debt to GDP data from the ECB and OECD datasets. We choose the period between 1999 and 2019. Our sample covers Austria, Belgium, Bulgaria, Cyprus, Germany, Denmark, Estonia, Spain, Finland, France, Croatia, Hungary, Ireland, Italy, Lithuania, Luxembourg, Malta, Poland, Portugal, Romania, Sweden, Slovenia, Slovakia, the Czech Republic, the Netherlands and the United Kingdom. For the majority of the countries in our sample, domestic gross government debt series as a share of GDP are readily available. For these countries, we calculate the average debt-to-GDP over 1999-2019. For Ireland and the United Kingdom, ECB only provides total debt values. Therefore, first, we calculate the average share of domestic debt in total debt from the OECD, which is the average share of marketable debt held by domestic residents in the total marketable debt. Because of data limitations for Ireland and the UK, we can construct the annual shares between 1999-2006 and between 1999-2010, respectively. We use these shares to calculate 
the domestic debt levels for Ireland and the UK, and divide them by the corresponding GDP series. Finally, the median domestic debt to GDP ratio for the whole sample between 1999-2019 is given by 25.8 percent.

We calculate the output volatility for GIIPS using the GDP per capita series obtained from OECD data between 1970-2019. First, for each country, we compute the standard deviation of HP-filtered log output. Then we compute the median across countries to obtain 3.4 percent. For moments related to the spread, we obtain interest rates for GIIPS from the OECD for 1999-2019. We calculate the spread as the difference between nominal yield on 10-year government bonds of each country and that of Germany. For each country, we compute the average and standard deviation of the spread and the correlation of spread and the HP-filtered GDP. Finally, we compute the medians of average spread, standard deviation of spread, and the correlation of spread with the GDP to obtain our moments.

\section{Data description for dynamics around banking crises}

To compute the sovereign yields, we use Jordà et al. (2017) Macrohistory database, which covers 1950-2016 and 17 advanced economies including Italy, Portugal and Spain. The sovereign yield is calculated as the nominal interest rate minus the inflation rate. Each country's output series is detrended using its own average growth rate. We define 7-year windows centered around banking crises. We compute unconditional averages across windows, as well as averages conditional on debt being above the country's $75^{\text {th }}$ percentile of debt at the start of the banking crisis. 


\section{Sensitivity Analysis}

In this appendix, we analyze our model's sensitivity to six parameters, i.e. bank's baseline capital $(\bar{A})$, household discount factor $(\beta)$, working capital constraint $(\gamma)$, financial shock shape $\left(\sigma_{\varepsilon}\right)$, probability of bank capital shock $(\pi)$, and labor share $(\alpha)$. When we change each parameter, keeping all other parameters fixed, we show how the simulated moments change in response. We also show that the main results - that banking crises lead to a higher likelihood of default and higher and more volatile spreads - are robust to these alternative parameter values.

1. Bank's baseline capital, $\bar{A}$. During defaults, the government is unable to give bailout transfers to help banks increase their liquidity. As a result, higher values of $\bar{A}$ reduce the cost of default in the model (because it increases the funds available for productive loans). As a result, the simulated model moments are sensitive to this parameter value, as can be seen in Table C.1. Nevertheless, the result that defaults are more likely following a banking crisis, along with higher and more volatile spreads, is robust to these alternative values of baseline capital.

Table C.1: Sensitivity to $\bar{A}$

\begin{tabular}{lcc}
\hline & Unconditional & Banking crisis \\
\hline Low $\bar{A}(\bar{A}=0.26)$ & & 0.5 \\
Default frequency & 0.5 & \\
Sovereign spread & & 0.8 \\
mean & 0.7 & 0.8 \\
standard deviation & 0.6 & 20.5 \\
Debt/GDP & 20.4 & 0.5 \\
Bailout/GDP & 0.3 & \\
\hline High $\bar{A}(\bar{A}=0.30)$ & & 1.1 \\
Default frequency & 0.5 & 1.4 \\
Sovereign spread & & 1.8 \\
mean & 0.7 & 11.9 \\
standard deviation & 0.8 & 3.1 \\
Debt/GDP & 11.6 & \\
Bailout/GDP & 1.4 & \\
\hline
\end{tabular}

Units: percent. The standard deviation is calculated based on HP-filtered residuals of the spread. 
2. Household discount parameter, $\beta$. Since the government represents the preferences of the households, a lower discount parameter (corresponding to less patience) results in an increase in both unconditional and conditional default frequencies, as well as spreads (Table C.2). There is also a slight increase in the amount of debt. The result that banking crises are associated with a higher likelihood of default and higher and more volatile spreads is robust to these alternative values.

Table C.2: Sensitivity to $\beta$

\begin{tabular}{lcc}
\hline & Unconditional & Banking crisis \\
\hline Low $\beta(\beta=0.76)$ & & \\
Default frequency & 0.9 & 1.1 \\
Sovereign spread & & \\
mean & 1.1 & 1.3 \\
standard deviation & 1.0 & 1.4 \\
Debt/GDP & 16.1 & 16.3 \\
Bailout/GDP & 0.8 & 1.5 \\
\hline High $\beta$ ( $\beta=0.86)$ & & \\
Default frequency & 0.3 & 0.5 \\
Sovereign spread & & \\
mean & 0.5 & 0.7 \\
standard deviation & 0.5 & 0.9 \\
Debt/GDP & 15.3 & 15.4 \\
Bailout/GDP & 0.9 & 1.9 \\
\hline
\end{tabular}

Units: percent. The standard deviation is calculated based on HP-filtered residuals of the spread. 
3. Working capital constraint, $\gamma$. The working capital constraint parameter determines the amount of working capital loans that firms demand. Higher values increase the demand for loans, which increases the loans' interest rate. With higher values of $\gamma$, we find that the government responds by injecting more liquidity into the financial system by increasing debt and reducing its utilization of bailouts, as shown in Table C.3. These actions reduce the 'diabolic loop' dynamics, making the likelihood of default more similar unconditionally and conditional on banking crises. Nevertheless, following a banking crisis, it is still the case that the government faces higher and more volatile spreads. Overall, we conclude that our results are robust to alternative values of $\gamma$.

Table C.3: Sensitivity to $\gamma$

\begin{tabular}{lcc}
\hline & Unconditional & Banking crisis \\
\hline Low $\gamma(\gamma=0.49)$ & & 0.9 \\
Default frequency & 0.7 & \\
Sovereign spread & & 1.4 \\
mean & 0.9 & 1.5 \\
standard deviation & 0.9 & 12.5 \\
Debt/GDP & 12.3 & 2.5 \\
Bailout/GDP & 1.1 & \\
\hline High $\gamma(\gamma=0.55)$ & & 0.6 \\
Default frequency & 0.6 & \\
Sovereign spread & & 0.9 \\
mean & 0.8 & 0.8 \\
standard deviation & 0.7 & 23.0 \\
Debt/GDP & 23.1 & 0.5 \\
Bailout/GDP & 0.2 & \\
\hline
\end{tabular}

Units: percent. The standard deviation is calculated based on HP-filtered residuals of the spread. 
4. Probability of bank capital shock, $\pi$. To examine the role of the bank capital shock in our results, we increase $\pi$ from 3 to 10 percent. In our model, the government promises bailout guarantees in the expectation of a banking crisis and thus, when the probability of having a banking crisis increases, the government becomes more reluctant to promise guarantees upfront knowing that the financing of that bailout will be costly once the shock hits. As shown in Table C.4, we find that bailout transfers decrease by about 30 percent when financial crises happen more often. Nevertheless, the result that banking crises lead to more frequent defaults and higher more volatile spreads is robust to this alternative value.

Table C.4: Sensitivity to $\pi$

\begin{tabular}{lcc}
\hline & Unconditional & Banking crisis \\
\hline Baseline $(\pi=0.03)$ & & 0.7 \\
Default frequency & 0.5 & \\
Sovereign spread & & 0.9 \\
mean & 0.7 & 1.0 \\
standard deviation & 0.6 & 16.0 \\
Debt/GDP & 15.5 & 1.7 \\
Bailout/GDP & 0.9 & \\
\hline High $\pi$ ( $\pi=0.10)$ & & 0.9 \\
Default frequency & 0.6 & \\
Sovereign spread & & 1.0 \\
mean & 0.8 & 1.2 \\
standard deviation & 0.7 & 16.7 \\
Debt/GDP & 16.6 & 1.2 \\
Bailout/GDP & 0.7 & \\
\hline
\end{tabular}

Units: percent. The standard deviation is calculated based on HP-filtered residuals of the spread. 
5. Financial shock shape, $\sigma_{\varepsilon}$. Due to the nonlinear effects of financial shocks on the real economy discussed in Section 4.5, the larger the volatility of the potential loss to banking capital, the higher is the need for bailouts. Indeed, Table C.5 shows that higher volatilities are associated with higher bailouts. However, they are also feature a higher default frequency, and higher and more volatile spreads. This is because the model generates a stronger 'diabolic loop.' The increase in the potential loss to banking capital creates higher incentives for the government to borrow to finance the bailouts, which increases the risk of default. Moreover, the property that banking crises entail higher likelihoods of default and higher and more volatile spreads is robust to these alternative values.

Table C.5: Sensitivity to $\sigma_{\varepsilon}$

\begin{tabular}{lcc}
\hline & Unconditional & Banking crisis \\
\hline $\begin{array}{l}\text { Low } \sigma_{\varepsilon}\left(\sigma_{\varepsilon}=3.76\right) \\
\text { Default frequency }\end{array}$ & 0.4 & 0.4 \\
Sovereign spread & & \\
mean & 0.6 & 0.6 \\
standard deviation & 0.5 & 0.5 \\
Debt/GDP & 22.4 & 22.5 \\
Bailout/GDP & 0.2 & 0.4 \\
\hline High $\sigma_{\varepsilon}\left(\sigma_{\varepsilon}=4.76\right)$ & & \\
Default frequency & 0.7 & 1.2 \\
Sovereign spread & & \\
mean & 1.0 & 1.6 \\
standard deviation & 1.0 & 1.9 \\
Debt/GDP & 12.3 & 12.5 \\
Bailout/GDP & 1.2 & 2.8 \\
\hline
\end{tabular}

Units: percent. The standard deviation is calculated based on HP-filtered residuals of the spread. 
6. Labor share, $\alpha$. Similar to the working capital constraint parameter, $\gamma$, the labor share parameter determines the amount of working capital loans demanded by firms. As such, changes in $\alpha$ have similar properties as changes in $\gamma$. If the labor share increases, the government chooses inject more liquidity into the banking sector by increasing government debt as opposed to relying on bailouts, reducing the 'diabolic loop' dynamics. As shown in Table C.6, with a higher labor share, we see that there is no significant difference between the unconditional default risk and the default risk conditional on banking crisis with higher labor share. The opposite dynamics are at work with a lower labor share: the government relies more on bailouts, increasing the 'diabolic loop' dynamics where banking crises are associated with spikes in the likelihood of default and higher and more volatile spreads.

Table C.6: Sensitivity to $\alpha$

\begin{tabular}{lcc}
\hline & Unconditional & Banking crisis \\
\hline $\begin{array}{l}\text { Low } \alpha(\alpha=0.67) \\
\text { Default frequency }\end{array}$ & 0.6 & 0.8 \\
Sovereign spread & & \\
mean & 0.8 & 1.3 \\
standard deviation & 0.9 & 1.6 \\
Debt/GDP & 12.2 & 12.5 \\
Bailout/GDP & 1.2 & 2.6 \\
\hline High $\alpha$ ( $\alpha=0.73)$ & & \\
Default frequency & 0.6 & 0.6 \\
Sovereign spread & & \\
mean & 0.8 & 0.9 \\
standard deviation & 0.7 & 0.7 \\
Debt/GDP & 22.1 & 22.0 \\
Bailout/GDP & 0.3 & 0.6 \\
\hline
\end{tabular}

Units: percent. The standard deviation is calculated based on HP-filtered residuals of the spread. 
7. Probability of financial redemption, $\theta$. To examine the role of financial redemption probability in our results, we increase $\theta$ from 0.5 to 0.7. As shown in Table C.7, increasing $\theta$ reduces the penalty of default, which leads to higher frequencies of default and lower debt capacity. Since the cost of default goes down, the government also has a higher tendency to issue bailouts because going into the 'diabolic loop' is not as destructive to the economy compared to the baseline.

Table C.7: Sensitivity to $\theta$

\begin{tabular}{lcc}
\hline & Unconditional & Banking crisis \\
\hline $\begin{array}{l}\text { Baseline }(\theta=0.50) \\
\text { Default frequency }\end{array}$ & 0.5 & 0.7 \\
Sovereign spread & & \\
mean & 0.7 & 0.9 \\
standard deviation & 0.6 & 1.0 \\
Debt/GDP & 15.5 & 16.0 \\
Bailout/GDP & 0.9 & 1.7 \\
\hline High $\theta$ ( $\theta=0.70)$ & & \\
Default frequency & 1.3 & 9.7 \\
Sovereign spread & & \\
mean & 1.5 & 11.3 \\
standard deviation & 2.3 & 21.9 \\
Debt/GDP & 6.3 & 16.7 \\
Bailout/GDP & 0.1 & 8.1 \\
\hline
\end{tabular}

Units: percent. The standard deviation is calculated based on HP-filtered residuals of the spread. 


\section{Computational appendix}

The model is solved using value function iteration with a discrete state space. We solve for the equilibrium of the finite-horizon version of our economy, increasing the number of periods of the finite-horizon economy until value functions and bond prices for the first and second periods of this economy are sufficiently close. Then, the first-period equilibrium objects are used as the infinite-horizon-economy equilibrium objects.

Algorithm. First, we specify initial guesses for the value of repayment $\left(V_{0}^{R}\right)$, and default $\left(V_{0}^{D}\right)$. We use as initial guesses the values at the last period of the finite-horizon version of the model, i.e. for a point $(b, s, A)$ in the state space we set

$$
\begin{aligned}
V_{(0)}^{R}(b, s, A) & =u\left(c_{\mathrm{LP}}^{*}, n_{\mathrm{LP}}^{*}\right) \\
V_{(0)}^{D}(b, s, A) & =u\left(c_{\mathrm{def} ; \mathrm{LP}}^{*}, n_{\text {def; LP }}^{*}\right)
\end{aligned}
$$

where $\left(c_{\mathrm{LP}}^{*}, n_{\mathrm{LP}}^{*}\right)$ are the optimal consumption and labor decisions in the last-period of the finite horizon economy (hence the LP subscript). A similar interpretation applies for ( $c_{\mathrm{def} \text {, LP }}^{*}$, $n_{\text {def; LP }}^{*}$, but under default. From these initial guesses, we can derive an initial guess for the default decision (being 1 if $V_{(0)}^{D}>V_{(0)}^{R}$ and 0 otherwise). We also compute and retain the equilibrium values of $r_{\mathrm{LP}}$, both under repayment and default: these values are needed to compute the bond price.

Second, using these initial guesses, we solve for the problem stated in (20)-(22) for each point in our discrete state space. In order to solve the problem under default we compute $\left(c_{\mathrm{def}}^{*}, n_{\mathrm{def}}^{*}, r_{\mathrm{def}}^{*}\right)$ following the equilibrium conditions in the private sector. With these allocations and prices we can get the new guess for the value of default, $V_{(1)}^{D}$.

To solve the problem under repayment we do the following for each combination $(b, s)$ :

1. Propose a candidate bailout, $T_{\mathrm{c}}$.

2. Given $\left(b, s, T_{\mathrm{c}}\right)$ solve for the optimal borrowing level by searching over the debt grid and selecting the level that maximizes $V^{R}\left(\cdot ; T_{\mathrm{c}}\right)$. Denote this level, $b_{\mathrm{c}}^{\prime}$. Note that this step involves solving the equilibrium of the private sector for each possible point in the state space and each given candidate transfer $T_{\mathrm{c}}$.

3. From all the candidate values of $T_{\mathrm{c}}$ (and associated $b_{\mathrm{c}}^{\prime}$ ), choose the one that maximizes $V^{R}$. This is done taking expectations over the possible realization of $A$ : $\bar{A}$ with probability $1-\pi$ or $(1-\varepsilon) \bar{A}$ with probability $\pi$.

4. Finally, update the guess for the value of repayment, $V_{(1)}^{R}$. 
From the process above we also recover (among other quantities and prices) $r^{*}$, which is the equilibrium loan rate. This rate needs to be saved in order to compute the bond price in subsequent iterations.

Third, we evaluate whether the maximum absolute deviation between the new and previous continuation values is below a give tolerance level. If it is, a solution has been found. If it is not, we repeat the optimization exercise using the new continuation values $V_{(1)}^{R}$ and $V_{(1)}^{D}$ to compute the expected value function at each grid point and to derive default probabilities which affect the price faced by the borrower. We repeat the procedure until the maximum absolute deviation between the new and previous continuation values is below a given tolerance level.

Implementation. We use the Tauchen method to discretize the TFP shocks in 25 states. We discretize the $\varepsilon$ shocks into four states in a one-sided application of the Tauchen method.

We use 50 evenly distributed grid points for debt. The debt grid is: $b \in[0,0.80]$. Recall that GDP is endogenous in our model: in the benchmark calibration, mean annual GDP is roughly 0.77 which implies our debt grid covers more than 100 percent of annual GDP.

The simulations presented in the main body of the paper come from the algorithm described in this appendix and allowing for the bailout to take any of 50 evenly distributed grid points ranging from zero to full coverage of the damage to the banking sector capital, i.e. $T_{\mathrm{c}} \in[0, \varepsilon \bar{A}]$. 